\title{
Advanced source apportionment of carbonaceous aerosols by coupling offline AMS and radiocarbon size-segregated measurements over a nearly 2-year period
}

\author{
Athanasia Vlachou ${ }^{1}$, Kaspar R. Daellenbach ${ }^{1}$, Carlo Bozzetti ${ }^{1}$, Benjamin Chazeau ${ }^{2}$, Gary A. Salazar ${ }^{3}$, Soenke Szidat ${ }^{3}$, \\ Jean-Luc Jaffrezo ${ }^{4}$, Christoph Hueglin ${ }^{5}$, Urs Baltensperger ${ }^{1}$, Imad El Haddad ${ }^{1}$, and André S. H. Prévôt ${ }^{1}$ \\ ${ }^{1}$ Laboratory of Atmospheric Chemistry, Paul Scherrer Institute, Villigen PSI, 5232, Switzerland \\ ${ }^{2}$ Aix-Marseille Université, CNRS, LCE, Marseille, France \\ ${ }^{3}$ Department of Chemistry and Biochemistry and Oeschger Centre for Climate Change Research, \\ University of Bern, 3012 Bern, Switzerland \\ ${ }^{4}$ Université Grenoble Alpes, CNRS, IRD, G-INP, IGE, 38000 Grenoble, France \\ ${ }^{5}$ Swiss Federal Laboratories for Materials Science and Technology, Empa, 8600 Dübendorf, Switzerland
}

Correspondence: André S. H. Prévôt (andre.prevot@psi.ch) and Imad El Haddad (imad.el-haddad@psi.ch)

Received: 27 November 2017 - Discussion started: 12 December 2017

Revised: 23 March 2018 - Accepted: 30 March 2018 - Published: 3 May 2018

\begin{abstract}
Carbonaceous aerosols are related to adverse human health effects. Therefore, identification of their sources and analysis of their chemical composition is important. The offline AMS (aerosol mass spectrometer) technique offers quantitative separation of organic aerosol (OA) factors which can be related to major OA sources, either primary or secondary. While primary OA can be more clearly separated into sources, secondary (SOA) source apportionment is more challenging because different sources - anthropogenic or natural, fossil or non-fossil - can yield similar highly oxygenated mass spectra. Radiocarbon measurements provide unequivocal separation between fossil and non-fossil sources of carbon. Here we coupled these two offline methods and analysed the OA and organic carbon (OC) of different size fractions (particulate matter below 10 and $2.5 \mu \mathrm{m}-\mathrm{PM}_{10}$ and $\mathrm{PM}_{2.5}$, respectively) from the Alpine valley of Magadino (Switzerland) during the years 2013 and 2014 (219 samples). The combination of the techniques gave further insight into the characteristics of secondary OC (SOC) which was rather based on the type of SOC precursor and not on the volatility or the oxidation state of $\mathrm{OC}$, as typically considered. Out of the primary sources separated in this study, biomass burning OC was the dominant one in winter, with average concentrations of $5.36 \pm 2.64 \mu \mathrm{g} \mathrm{m}^{-3}$ for $\mathrm{PM}_{10}$ and $3.83 \pm 1.81 \mu \mathrm{g} \mathrm{m}^{-3}$ for $\mathrm{PM}_{2.5}$, indicating that wood combustion particles were predominantly generated in the fine
\end{abstract}

mode. The additional information from the size-segregated measurements revealed a primary sulfur-containing factor, mainly fossil, detected in the coarse size fraction and related to non-exhaust traffic emissions with a yearly average $\mathrm{PM}_{10}\left(\mathrm{PM}_{2.5}\right)$ concentration of $0.20 \pm 0.24 \mu \mathrm{g} \mathrm{m}{ }^{-3}$ $\left(0.05 \pm 0.04 \mu \mathrm{g} \mathrm{m}^{-3}\right)$. A primary biological OC (PBOC) was also detected in the coarse mode peaking in spring and summer with a yearly average $\mathrm{PM}_{10}\left(\mathrm{PM}_{2.5}\right)$ concentration of $0.79 \pm 0.31 \mu \mathrm{g} \mathrm{m}^{-3}\left(0.24 \pm 0.20 \mu \mathrm{g} \mathrm{m}^{-3}\right)$. The secondary OC was separated into two oxygenated, non-fossil OC factors which were identified based on their seasonal variability (i.e. summer and winter oxygenated organic carbon, OOC) and a third anthropogenic OOC factor which correlated with fossil OC mainly peaking in winter and spring, contributing on average $13 \% \pm 7 \%(10 \% \pm 9 \%)$ to the total OC in $\mathrm{PM}_{10}\left(\mathrm{PM}_{2.5}\right)$. The winter OOC was also connected to anthropogenic sources, contributing on average $13 \% \pm 13 \%$ $(6 \% \pm 6 \%)$ to the total $\mathrm{OC}$ in $\mathrm{PM}_{10}\left(\mathrm{PM}_{2.5}\right)$. The summer OOC (SOOC), stemming from oxidation of biogenic emissions, was more pronounced in the fine mode, contributing on average $43 \% \pm 12 \%(75 \% \pm 44 \%)$ to the total OC in $\mathrm{PM}_{10}$ $\left(\mathrm{PM}_{2.5}\right)$. In total the non-fossil OC significantly dominated the fossil OC throughout all seasons, by contributing on average $75 \% \pm 24 \%$ to the total OC. The results also suggested that during the cold period the prevailing source was residential biomass burning while during the warm period primary 
biological sources and secondary organic aerosol from the oxidation of biogenic emissions became important. However, SOC was also formed by aged fossil fuel combustion emissions not only in summer but also during the rest of the year.

\section{Introduction}

The field deployment of the time-of-flight aerosol mass spectrometer (HR-ToF-AMS, Canagaratna et al., 2007) has advanced our understanding of aerosol chemistry and dynamics. The HR-ToF-AMS provides quantitative mass spectra of the non-refractory particle component, including, but not limited to, organic aerosol (OA), ammonium sulfate and nitrate, by combining the flash vaporization of particle species and the electron ionization of the resulting gases. The application of positive matrix factorization (PMF, Paatero, 1997) techniques has demonstrated that the collected OA mass spectra contain sufficient information to quantitatively distinguish aerosol sources. However, the cost and intensive maintenance requirements of this instrument significantly hinder its systematic, long-term deployment as part of a dense network and most applications are limited to few weeks of measurements (Jimenez et al., 2009; El Haddad et al., 2013; Crippa et al., 2013). This information is critical for model validation and policy directives. The Aerodyne aerosol chemical speciation monitors (ACSM, Ng et al., 2011; Fröhlich et al., 2013) were developed as a lowcost, low-maintenance alternative to the AMS; however, their reduced chemical resolution can limit the factor separation achievable by source apportionment.

The recent utilization of the AMS for the offline analysis of ambient filter samples (Daellenbach et al., 2016) has significantly broadened the spatial and temporal scales accessible to high-resolution AMS measurements (Daellenbach et al., 2017; Bozzetti et al., 2017a, b). In addition, the technique enables measurement of aerosol composition outside the normal size transmission window of the AMS; the standard AMS can measure up to only $1 \mu \mathrm{m}$, or $\sim 2.5 \mu \mathrm{m}$ with a newly developed aerodynamic lens (Williams et al., 2013; Elser et al., 2016). This capability has been used to quantify the contributions of primary biological organic aerosol to OA in $\mathrm{PM}_{10}$ filters (Bozzetti et al., 2016). Finally, the offline AMS technique allows a retrospective reaction to critical air quality events. For example, one of the applications of this approach had been to examine a severe haze event in China which affected a total area of $\sim 1.3$ million $\mathrm{km}^{2}$ and $\sim 800$ million people (Huang et al., 2014).

A major limitation of the technique is the resolution of low water solubility fractions, as the recoveries of some of them are not accessible. Despite this, source apportionment results obtained using this technique are in good agreement with online AMS or ACSM measurements. PMF analysis of offline AMS data has yielded factors related with primary emissions from traffic, biomass burning and coal burning, and secondary organic aerosols (SOA) differentiated according to their different seasonal contributions. Nevertheless, the identification of SOA precursors using the AMS has proven challenging, due to the evolution of different precursors towards chemically similar species and the extensive fragmentation by the electron ionization used in the AMS.

The radiocarbon $\left({ }^{14} \mathrm{C}\right)$ analysis of particulate matter has proven to be a powerful technique providing an unequivocal distinction between non-fossil (e.g. biomass burning and biogenic emissions) and fossil (e.g. traffic exhaust emissions and coal burning) sources (Lemire et al., 2002; Szidat et al., 2004, 2009). The measurement of the ${ }^{14} \mathrm{C}$ content of total carbon (TC), which comprises the elemental carbon (EC) originating from combustion sources and the organic carbon (OC), had been the subject of many studies (Schichtel et al., 2008; Glasius et al., 2011; Genberg et al., 2011; Zhang et al., 2012, , 2016; Zotter et al., 2014b; Bonvalot et al., 2016). Results have shown that in European sites, especially in Alpine valleys, the non-fossil sources play an important role during winter due to biomass burning and in summer due to biogenic sources (Gelencsér et al., 2007; Zotter et al., 2014b). Moreover, at regional background sites close to urbanized areas in Europe (Dusek et al., 2017) as well as in megacities such as Los Angeles and Beijing, fossil OA may also exhibit significant contributions to the total OA (Zotter et al., 2014a; Zhang et al., 2017). However, the determination of the ${ }^{14} \mathrm{C}$ content in EC and OC separately is challenging and therefore not often attempted for extended datasets.

The coupling of the offline AMS/PMF with radiocarbon analysis provides further insight into the sources of organic aerosols and in particular those related to SOA precursors. Such combination has been already attempted (Minguillón et al., 2011; Zotter et al., 2014a; Huang et al., 2014; Beekmann et al., 2015; Ulevicius et al., 2016); however, the focus has rather been on high OA concentration episodes, while little is known about the yearly cycle of the most important SOA precursors and the size resolution of the different fossil and non-fossil OA fractions.

Here, we present offline AMS measurements of a total of 219 samples, 154 of which are $\mathrm{PM}_{10}$ samples representative of the years 2013 and 2014 and $65 \mathrm{PM}_{2.5}$ concurrent with $\mathrm{PM}_{10}$ samples for the year 2014 (January to September). ${ }^{14} \mathrm{C}$ analysis was also performed on a subset of $33 \mathrm{PM}_{10}$ samples, covering the year 2014. The size-segregated samples offered better insights into the mechanism by which the different fractions enter the atmosphere, while the coupling of offline $\mathrm{AMS} / \mathrm{PMF}$ and ${ }^{14} \mathrm{C}$ analysis provided a more profound understanding of the SOA fossil and non-fossil precursors on a yearly basis. 


\section{Methods}

\subsection{Site and sampling collection}

Magadino is located in an Alpine valley in the Southern part of Switzerland, south of the Alps (Fig. S1 in the Supplement). The station $\left(46^{\circ} 9^{\prime} 37^{\prime \prime} \mathrm{N}, 8^{\circ} 56^{\prime} 2^{\prime \prime} \mathrm{E}, 204 \mathrm{~m}\right.$ a.s.l.) belongs to the Swiss National Air Pollution Monitoring Network (NABEL) and is classified as a rural background site. It is located relatively far from busy roads or residential areas and surrounded by agricultural fields and forests. It is ca. $1.4 \mathrm{~km}$ away from Cadenazzo train station, ca. $8 \mathrm{~km}$ from Lake Maggiore (Lago Maggiore) and ca. $7 \mathrm{~km}$ from the small Locarno Airport.

The filter samples under examination are $24 \mathrm{~h}$ integrated $\mathrm{PM}_{10}$ (from 4 January 2013 to 28 September 2014, with a 4-day interval) and $\mathrm{PM}_{2.5}$ (from 3 January to 28 September 2014, with a 4-day interval). PM was sampled and collected on $14 \mathrm{~cm}$ (exposed diameter) quartz fibre filters, using a high volume sampler $\left(500 \mathrm{~L} \mathrm{~min}^{-1}\right)$. After the sampling, filter samples and field blanks were wrapped in lint-free paper and stored at $-20^{\circ} \mathrm{C}$.

\subsection{Offline AMS method}

The offline AMS method is thoroughly described by Daellenbach et al. (2016). Briefly, four punches of $16 \mathrm{~mm}$ diameter from each filter sample are extracted in $15 \mathrm{~mL}$ of ultrapure water $\left(18.2 \mathrm{M} \Omega \mathrm{cm}\right.$ at $25^{\circ} \mathrm{C}$ with total organic carbon, TOC, $<3 \mathrm{ppb}$ ), followed by insertion in an ultra-sonic bath for $20 \mathrm{~min}$ at $30^{\circ} \mathrm{C}$. The water-extracted samples are then filtered through a $0.45 \mu \mathrm{m}$ nylon membrane syringe and inserted to an Apex Q nebulizer (Elemental Scientific Inc., Omaha, NE, USA) operating at $60^{\circ} \mathrm{C}$. The resulting aerosols generated in $\operatorname{Ar}$ ( $\geq 99.998 \%$ vol., Carbagas, 3073, Gümligen, Switzerland) were dried by a Nafion dryer and subsequently injected and analysed by the HR-ToF-AMS.

To correct for the interference of $\mathrm{NH}_{4} \mathrm{NO}_{3}$ on the $\mathrm{CO}_{2}^{+}$ signal as described in Pieber et al. (2016), several dilutions of $\mathrm{NH}_{4} \mathrm{NO}_{3}$ in ultrapure water were measured regularly as well. The $\mathrm{CO}_{2}^{+}$signal was then calculated as

$\mathrm{CO}_{2, \text { real }}=\mathrm{CO}_{2 \text {,meas }}-\left(\frac{\mathrm{CO}_{2, \text { meas }}}{\mathrm{NO}_{3, \text { meas }}}\right)_{\mathrm{NH}_{4} \mathrm{NO}_{3, \text { pure }}} \cdot \mathrm{NO}_{3 \text {, meas }}$,

where $\mathrm{CO}_{2 \text {,real }}$ represents the corrected $\mathrm{CO}_{2}^{+}$signal, $\mathrm{CO}_{2 \text {,meas }}$ and $\mathrm{NO}_{3 \text {, meas }}$ are signals from the samples mea-

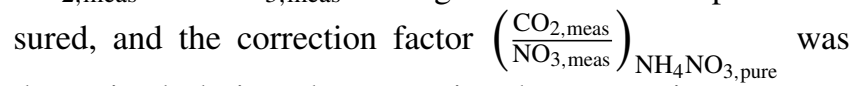
determined during the campaign by measuring aqueous $\mathrm{NH}_{4} \mathrm{NO}_{3}$.

\section{$2.3{ }^{14} \mathrm{C}$ analysis}

Based on the instrumentation setup described in Agrios et al. (2015) and on the method described in Zotter et al. (2014b), radiocarbon analysis of TC and EC was conducted on a set of 33 filters. The ${ }^{14} \mathrm{C}$ content of blank filters was measured for TC only, as there was no EC found on these filters. All the ${ }^{14} \mathrm{C}$ results are given in fractions of modern carbon $\left(f_{\mathrm{M}}\right)$ representing the ${ }^{14} \mathrm{C} /{ }^{12} \mathrm{C}$ ratios of each sample relative to the respective ${ }^{14} \mathrm{C} /{ }^{12} \mathrm{C}$ ratio of the reference year 1950 (Stuiver and Polach, 1977).

\subsection{1 ${ }^{14} \mathrm{C}$ measurements of $\mathrm{TC}$}

For the determination of the ${ }^{14} \mathrm{C}$ content of TC, a Sunset OC / EC analyser (Model 4L, Sunset Laboratory, USA) equipped with a non-dispersive infrared (NDIR) detector was first used in order to combust each filter punch $\left(1.5 \mathrm{~cm}^{2}\right)$ under pure $\mathrm{O}_{2}(99.9995 \%)$ at $760^{\circ} \mathrm{C}$ for $400 \mathrm{~s}$. The generated $\mathrm{CO}_{2}$ was then captured online by a zeolite trap within a gas inlet system (GIS) and then injected in the accelerator mass spectrometer (AMS*) mini carbon dating system (MICADAS) at the Laboratory for the Analysis of Radiocarbon with AMS* (LARA), University of Bern, Switzerland (Szidat et al., 2014) for ${ }^{14} \mathrm{C}$ measurement. (Note that we used AMS* and AMS as abbreviations for the accelerator mass spectrometer and the aerosol mass spectrometer, respectively, to avoid confusion.)

The $f_{\mathrm{M}}$ of TC underwent a blank correction following an isotopic mass balance approach:

$f_{\mathrm{M}_{\mathrm{b}, \text { cor }}}=\frac{\mathrm{mC}_{\text {sample }} \cdot f_{\mathrm{M}, \text { sample }}-\mathrm{mC}_{\mathrm{b}} \cdot f_{\mathrm{M}, \mathrm{b}}}{\mathrm{mC}_{\mathrm{sample}}-\mathrm{mC}_{\mathrm{b}}}$,

where $f_{\mathrm{M}_{\mathrm{b}, \text { cor }}}$ is the blank corrected $f_{\mathrm{M}} ; \mathrm{mC}_{\text {sample }}$ and $\mathrm{mC}_{\mathrm{b}}$ are the carbon mass in sample and blank, respectively; and $f_{\mathrm{M} \text {,sample }}$ and $f_{\mathrm{M}, \mathrm{b}}$ are the $f_{\mathrm{M}}$ measured for sample and blank, respectively. Error propagation was applied for the determination of the $f_{\mathrm{M}_{\mathrm{b}, \text { cor }}}$ uncertainty. The $f_{\mathrm{M}, \mathrm{b}}$ was $0.61 \pm 0.10$ and the concentration of the blank $1.1 \pm 0.2 \mu \mathrm{g} \mathrm{C} \mathrm{m}^{-3}$.

\subsection{2 ${ }^{14} \mathrm{C}$ measurements of $\mathrm{EC}$}

For the EC isolation of the samples, each filter punch $\left(1.5 \mathrm{~cm}^{2}\right)$ was analysed by the Sunset EC / OC analyser with the use of the Swiss_4S protocol developed by Zhang et al. (2012). According to the protocol, the heating is conducted in four different steps under different gas conditions: step one under pure $\mathrm{O}_{2}$ at $375^{\circ} \mathrm{C}$ for $150 \mathrm{~s}$, step two under pure $\mathrm{O}_{2}$ at $475^{\circ} \mathrm{C}$ for $180 \mathrm{~s}$, step three under $\mathrm{He}(>99.999 \%)$ at $450^{\circ} \mathrm{C}$ for $180 \mathrm{~s}$ followed by an increase in the temperature up to $650^{\circ} \mathrm{C}$ for another $180 \mathrm{~s}$, and step four under pure $\mathrm{O}_{2}$ at $760^{\circ} \mathrm{C}$ for $150 \mathrm{~s}$. Each filter sample was previously water extracted and dried, in order to minimize the positive artefact induced by the OC by removing the water-soluble OC (WSOC), which is known to produce charring (Piazzalunga et al., 2011; Zhang et al., 2012). By this method, the waterinsoluble OC (WINSOC) was removed during the first three steps of the Swiss_4S protocol. In the fourth step, EC was 
combusted and then trapped in the GIS and measured by the AMS* MICADAS, as described above.

This protocol was preferred over the protocols commonly used in thermo-optical methods (EUSAAR 2 or NIOSH) because it optimises the separation of the two fractions OC and EC by minimizing (i) the positive artefact of charring produced by WSOC during the first three steps and (ii) the premature losses, during the removal of the WINSOC in the third step, of the less refractory part of EC which may preferentially originate from non-fossil sources such as biomass burning.

Following a similar principle to Zotter et al. (2014b), both charring and EC yield, which is the part of EC that remained on the filter after step three and before step four in the Swiss_4S protocol, were quantified and corrected for with the help of the laser mounted on the Sunset analyser. The laser transmittance is monitored continuously during the heating process. Charring in step three was quantified as

Charring $_{S_{3}}=\frac{\operatorname{maxATN} \mathrm{S}_{3}-\text { initial } \mathrm{ATN}_{\mathrm{S}_{2}}}{\text { initial } \mathrm{ATN}_{\mathrm{S}_{1}}}$,

where ATN refers to the laser attenuation, $\max \mathrm{ATN}_{\mathrm{S}_{3}}$ is the maximum attenuation in step three, and initial $\mathrm{ATN}_{\mathrm{S}_{2}}$ and initial $\mathrm{ATN}_{\mathrm{S}_{1}}$ are the initial attenuations in step two and one, respectively.

The EC yield in step three was quantified as

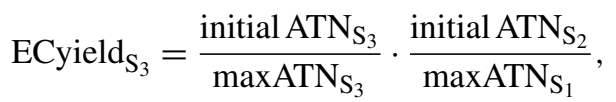

The average charred OC was found to be $4 \pm 2 \%$ and the recovered EC for all samples was on average $71 \pm 7 \%$.

As there is a linear relationship between the fraction of modern carbon for $\mathrm{EC}\left(f_{\mathrm{M}_{\mathrm{EC}}}\right)$ and the EC yield (Zhang et al., 2012), the slope can be used to extrapolate $f_{\mathrm{M}_{\mathrm{EC}}}$ to $100 \%$ EC yield. According to Zotter et al. (2014), a slope of $0.35 \pm 0.11$ was considered to correct all $f_{\mathrm{M}_{\mathrm{EC}}}$ to $100 \%$ of EC yield, such that

$f_{\mathrm{M}_{\mathrm{EC}, \text { total }}}=$ slope $\cdot\left(1-\right.$ ECyield $\left._{\mathrm{S}_{3}}\right)+f_{\mathrm{M}_{\mathrm{EC}}} \cdot$

\subsubsection{Calculation of ${ }^{14} \mathrm{C}$ content of $\mathrm{OC}$}

The fraction of modern carbon of OC $\left(f_{\mathrm{M}_{\mathrm{OC}}}\right)$ was calculated following a mass balance approach:

$f_{\mathrm{M}_{\mathrm{OC}}}=\frac{\mathrm{TC} \cdot f_{\mathrm{M}_{\mathrm{TC}}}-\mathrm{EC} \cdot f_{\mathrm{M}_{\mathrm{EC}}}}{\mathrm{TC}-\mathrm{EC}}$,

where TC and EC are the concentrations of total and elemental carbon, respectively, and $f_{\mathrm{M}_{\mathrm{TC}}}$ and $f_{\mathrm{M}_{\mathrm{EC}}}$ are the fractions of modern carbon of TC and EC, respectively. The uncertainty of $f_{\mathrm{M}_{\mathrm{OC}}}$ was calculated by propagating the error of each component of Eq. (6).

\subsubsection{Nuclear bomb peak correction}

The expected $f_{\mathrm{M}}$ coming from fossil samples should be equal to zero due to the complete decay of ${ }^{14} \mathrm{C}$ until now, whereas the $f_{\mathrm{M}}$ from non-fossil samples is expected to be unity. However, due to the extensive nuclear bomb testing during the late 1950s and early 1960s, the radiocarbon amount in the atmosphere increased dramatically because of the high neutron flux during the explosions. Therefore the measured $f_{\mathrm{M}}$ of non-fossil samples may exhibit values greater than one (Levin et al., 2010a). To correct for this effect, the $f_{M}$ is normalized to a reference non-fossil fraction $\left(f_{\mathrm{NF}, \text { ref }}\right)$ which represents the amount of ${ }^{14} \mathrm{C}$ currently in the atmosphere compared to 1950, before the nuclear bomb tests. As EC comes from either biomass burning or fossil sources, the non-fossil fraction of $\mathrm{EC}$ ( $f_{\mathrm{NF}, \mathrm{EC}}$ ) equals the $f_{\mathrm{M}}$ coming from biomass burning $\left(f_{\mathrm{M}, \mathrm{bb}}\right)$. The latter was estimated by a tree growth model (Mohn et al., 2008) and was equal to 1.101. The nonfossil fraction of OC $\left(f_{\mathrm{NF}, \mathrm{OC}}\right)$ is calculated as

$f_{\mathrm{NF}, \mathrm{OC}}=p_{\mathrm{bio}} \cdot f_{\mathrm{M}, \mathrm{bio}}+p_{\mathrm{bb}} \cdot f_{\mathrm{M}, \mathrm{bb}}$,

where $f_{\mathrm{M} \text {, bio }}(=1.023)$ is the fraction of modern carbon of biogenic sources and was estimated from ${ }^{14} \mathrm{CO}_{2}$ measurements in Schauinsland (Levin et al., 2010a). The fractions of biogenic sources ( $\left.p_{\text {bio }}\right)$ and biomass burning $\left(p_{\mathrm{bb}}\right)$ to the total non-fossil sources were set to 0.5 since both sources are important in Magadino during the year (biomass burning in winter, biogenic sources in summer).

\subsection{Additional measurements}

Organic and elemental carbon fractions were determined by a Sunset EC / OC analyser with the use of the EUSAAR-2 thermal-optical transmittance protocol (Cavalli et al., 2010). Water-soluble organic carbon was measured by a total organic carbon analyser (Jaffrezo et al., 2005) with the use of catalytic oxidation of water-extracted filter samples and detection of the resulting $\mathrm{CO}_{2}$ with an NDIR. The concentrations of major ionic species $\left(\mathrm{K}^{+}, \mathrm{Na}^{+}, \mathrm{Mg}^{2+}, \mathrm{Ca}^{2+}\right.$, $\mathrm{NH}_{4}^{+}, \mathrm{Cl}^{-}, \mathrm{NO}_{3}^{-}$and $\mathrm{SO}_{4}^{2-}$ ) as well as methane sulfonic acid (MSA) were determined by ion chromatography (Jaffrezo et al., 1998). Anhydrous sugars (levoglucosan, mannosan, galactosan) were analysed by an ion chromatograph (Dionex ICS3000) using high-performance anion exchange chromatography (HPAEC) with pulsed amperometric detection. Cellulose was analysed by performing enzymatic conversion of cellulose to D-glucose (Kunit and Puxbaum, 1996) and D-glucose was determined by HPAEC.

\section{Source apportionment}

\subsection{Method}

The obtained organic mass spectra from the offline AMS measurements were analysed by positive matrix factoriza- 
tion (Paatero and Tapper, 1994; Ulbrich et al., 2009). PMF attempts to solve the bilinear matrix equation,

$\mathbf{X}_{i j}=\sum_{k} \mathbf{G}_{i, k} \mathbf{F}_{k, j}+\mathbf{E}_{i, j}$,

by following the weighted least-squares approach. In the case of aerosol mass spectrometry, $i$ represents the time index, $j$ the fragment and $k$ the factor number. If $\mathbf{X}_{i j}$ is the matrix of the organic mass spectral data and $\mathbf{s}_{i, j}$ the corresponding error matrix, $\mathbf{G}_{i, k}$ the matrix of the factor time series, $\mathbf{F}_{k, j}$ the matrix of the factor profiles and $\mathbf{E}_{i, j}$ the model residual matrix, then PMF determines $\mathbf{G}_{i, k}$ and $\mathbf{F}_{k, j}$ such that the ratio of the Frobenius norm of $\mathbf{E}_{i, j}$ over $\mathbf{s}_{i, j}$ is minimized. The allowed $\mathbf{G}_{i, k}$ and $\mathbf{F}_{k, j}$ are always non-negative. The input error matrix $\mathbf{s}_{i, j}$ includes the measurement uncertainty (ion-counting statistics and ion-to-ion signal variability at the detector) (Allan et al., 2003) as well as the blank variability. Fragments with a signal-to-noise ratio (SNR) below 0.2 were removed and the ones with SNR lower than 2 were down-weighted by a factor of 3 , as recommended by Paatero and Hopke (2003). Both input data and error matrices were scaled to the calculated water-soluble organic matter $\left(\mathrm{WSOM}_{i}\right)$ concentration:

$\mathrm{WSOM}_{i}=\frac{\mathrm{OM}}{\mathrm{OC}} \cdot \mathrm{WSOC}_{i}$,

where $\frac{\mathrm{OM}}{\mathrm{OC}}$ is determined from the AMS measurements and $\mathrm{WSOC}_{i}$ is the water-soluble OC measured by the TOC analyser.

The Source Finder toolkit (SoFi v.4.9, Canonaco et al., 2013) for IGOR Pro software package (Wavemetrics, Inc., Portland, OR, USA) was used to run the PMF algorithm. The PMF was solved by the multilinear engine 2 (ME-2, Paatero, 1999), which allows the constraining of the $\mathbf{F}_{k, j}$ elements to vary within a certain range defined by the scalar $\alpha$ $(0 \leq \alpha \leq 1)$, such that the modelled $\mathbf{F}_{k, j}^{\prime}$ equals

$\mathbf{F}_{k, j}^{\prime}=\mathbf{F}_{k, j} \pm \alpha \cdot \mathbf{F}_{k, j}$.

Here we constrained only the hydrocarbon-like factor (HOA) from high-resolution mass spectra analysed by Crippa et al. (2013).

\subsection{Sensitivity analysis}

To understand the variability of our dataset we explored 4-10 factor solutions and retained the 7-factor solution as the best representation of the data. The exploration of the PMF solutions is thoroughly described in Sect. S.1 in the Supplement.

We assessed the accuracy of PMF results by bootstrapping the input data (Davison and Hinkley, 1997). New input data and error matrices were created by randomly resampling the time series from the original input matrix (223 samples in total: $219+4$ remeasurements from the $\mathrm{PM}_{10}$ samples), with replacement; i.e. any sample from the whole population can be resampled more than once. Each sample measurement included on average blocks of 12 mass spectral repetitions; therefore, resampling was performed on the blocks. Out of the 223 original samples, some of them were represented several times, while some others not at all. Overall, the resampled data made up on average $64 \pm 2 \%$ of the total original data per bootstrap run. We performed 180 bootstrap runs, with each of the generated matrices being perturbed by varying the $\mathbf{X}_{i j}$ element within twice the corresponding error matrix $\mathbf{s}_{i, j}$. Within the resampling operation, the $\alpha$ value used to set the HOA constraining strength was varied between 0 and 1 with an increment of 0.1 to assess the sensitivity of the results on the $\alpha$ value.

To select the physically plausible solutions we applied two criteria:

1. We accepted solutions where the average absolute concentrations of all factors in $\mathrm{PM}_{2.5}$ did not statistically significantly exceed their concentrations in $\mathrm{PM}_{10}$. For this we performed a paired $t$ test with a significance level of 0.01 (Fig. S2 and Table S1 in the Supplement).

2. We excluded outlier solutions identified by examining the correlation of factor time series from bootstrap runs with their respective factor time series from the average of all bootstrap runs. The rejected solutions included factors that did not correlate with the corresponding average factor time series, meaning that one of the factors was not separated (Fig. S3 in the case of water-soluble primary biological organic carbon, $\mathrm{PBOC}$ ).

In total 24 bootstrap runs were retained after the application of the aforementioned criteria.

\subsection{Recoveries}

In order to rescale the WSOC concentration of a factor $k$ to its total concentration $\mathrm{OC}_{k}$, we used factor recoveries $\left(R_{k}\right)$ as proposed by Daellenbach et al. (2016). First, the $\mathrm{WSOM}_{k}$ was calculated as

$\mathrm{WSOM}_{k}=f_{k, \mathrm{WSOM}} \cdot \mathrm{WSOC}_{\text {measured }} \cdot\left(\frac{\mathrm{OM}}{\mathrm{OC}}\right)_{\text {bulk }}$,

where

$f_{k, \mathrm{WSOM}}=\frac{\mathrm{WSOM}_{k, \text { measured }}}{\sum_{k} \mathrm{WSOM}_{k, \text { measured }}}$

and

$\left(\frac{\mathrm{OM}}{\mathrm{OC}}\right)_{\text {bulk }}$

is estimated from the input data matrix for the PMF.

The $\mathrm{WSOM}_{k}$ was converted to $\mathrm{WSOC}_{k}$ to fit the measured OC concentrations (determined by the Sunset EC / OC analyser). The $\mathrm{WSOC}_{k}$ was determined as

$\mathrm{WSOC}_{k}=\frac{f_{k, \mathrm{WSOM}} \cdot \mathrm{WSOC}_{\text {measured }} \cdot\left(\frac{\mathrm{OM}}{\mathrm{OC}}\right)_{\text {bulk }}}{\left(\frac{\mathrm{OM}}{\mathrm{OC}}\right)_{k}}$, 
where $\left(\frac{\mathrm{OM}}{\mathrm{OC}}\right)_{k}$ is calculated from each factor profile.

Finally, the recoveries were applied following Eq. (15):

$\mathrm{OC}_{i, k}=\frac{\mathrm{WSOC}_{i, k}}{R_{k}}$

To assess the recoveries and their uncertainties, we evaluated the sum of $\mathrm{OC}_{i, k}$ against the measured $\mathrm{OC}\left(\mathrm{OC}_{i, \text { measured }}\right)$ by fitting Eq. (16). The starting values for the $R_{k}$ fitting were based on Bozzetti et al. (2016) (for $R_{\mathrm{PBOA}}$ ) and Daellenbach et al. (2016) except $R_{\mathrm{SCOA}}$, which was randomly varied between 0 and 1 (increment: $10^{-4}$ ). While $R_{\mathrm{HOA}}$ and $R_{\mathrm{SCOA}}$ were constrained, $R_{\mathrm{PBOA}}, R_{\mathrm{BBOA}}, R_{\mathrm{WOOA}}, R_{\mathrm{AOOA}}$ and $R_{\mathrm{SOOA}}$ were determined by a non-negative multilinear fit (see below in Sect. 4.3 for a description of these PMF factors from offline AMS results). The multilinear fit was chosen to be non-negative because a negative $R_{k}$ would mean a negative concentration of $\mathrm{WSOC}_{k}$ or $\mathrm{OC}_{k}$. The fit was performed 100 times for each of the retained bootstrap solutions.

$\mathrm{OC}_{i, \text { measured }}=\sum_{k} \frac{\mathrm{WSOC}_{i, k}}{R_{k}}$

Each fit was initiated by perturbing the $\mathrm{OC}_{i, k}$ and the $\mathrm{WSOC}_{i, k}$ concentrations within their uncertainties, assuming a normal distribution of errors, to assess the influence of measurement precision on $R_{k}$. Additionally, we introduced a constant $5 \%$ accuracy bias corresponding to the $\mathrm{OC}$ and WSOC measurement accuracy.

To select the environmentally meaningful solutions we applied the following criteria:

1. To retain the recoveries that achieved the OC mass closure, we estimated the OC residuals and discarded solutions where OC residuals were statistically different from 0 within 1 standard deviation for each size fraction individually and for winter and summer individually.

2. We also examined the dependence between the WSOC residuals and each factor $\mathrm{WSOC}_{i, k}(t$ test, $\alpha=0.001)$. Overall, $55 \%$ of the solutions were retained.

3. The physically plausible range of the recoveries is $[0$, 1]. However, the mathematically possible range can exceed the upper limit. $R_{k}$ larger than 1 would mean that $\mathrm{WSOC}_{k}$ is larger than $\mathrm{OC}_{k}$ and is, therefore, nonphysical. For this reason, out of the accepted solutions that survived the previous two criteria, the retained $R_{k}$ combinations were weighted according to their physical interpretability. More specifically, fitting results with $R_{k}$ larger than 1 were down-weighted according to the measurement uncertainties of WSOC and OC (see Sect. S.2, Fig. S4).

\section{Results and discussion}

\subsection{PM $_{10}$ composition}

$\mathrm{PM}_{10}$ in Magadino has been characterized by high carbonaceous concentrations during winter (Gianini et al., 2012a; Zotter et al., 2014b). This is clearly illustrated in Fig. 1 where an overview of the $\mathrm{PM}_{10}$ composition is presented in Fig. 1a with Fig. $1 \mathrm{~b}$ and c summarizing the concentrations and relative contributions of each component to the total $\mathrm{PM}_{10}$ averaged per season. The peaks of OM and EC during winter (daily averages up to 26 and $5.9 \mu \mathrm{g} \mathrm{m}^{-3}$, respectively) are indications of the increased wood-burning activity. Other Alpine sites close to Magadino, such as Roveredo and San Vittore in Switzerland, have also exhibited high OM concentrations due to residential wood burning (Szidat et al., 2007, for $\mathrm{PM}_{10}$ in Roveredo, Lanz et al., 2010, for $\mathrm{PM}_{1}$ in Roveredo and Zotter et al., 2014b, for PM $\mathrm{PM}_{10}$ in San Vittore and Roveredo). The organic contribution dominated the inorganic fraction not only in winter, but also throughout both years (Fig. 1c). Note that the EC concentrations are much lower in spring compared to winter (Fig. 1b). The main inorganic aerosols contributing to the total PM are $\mathrm{NO}_{3}^{-}, \mathrm{SO}_{4}^{2-}$ and $\mathrm{NH}_{4}^{+} . \mathrm{NO}_{3}^{-}$represented the second major component of $\mathrm{PM}_{10}$, exhibiting a seasonal cycle with higher concentrations during winter $\left(2.9 \mathrm{\mu g} \mathrm{m}^{-3}\right)$. The notable discrepancy of $\mathrm{NO}_{3}^{-}$concentrations between the first (2013) and second (2014) winter could be explained by the lower temperatures in January-February 2013 compared to 2014. Conversely, $\mathrm{SO}_{4}^{2-}$ showed a rather stable yearly cycle with slightly higher concentrations in summer $\left(1.9 \mu \mathrm{g} \mathrm{m}^{-3}\right) \mathrm{com}-$ pared to winter $\left(1.3 \mu \mathrm{g} \mathrm{m}^{-3}\right)$, despite a shallower boundary layer height in winter.

\section{2 ${ }^{14} \mathrm{C}$ analysis results}

So far radiocarbon results have been reported mostly for relatively short periods of time (Bonvalot et al., 2016), mainly describing high concentration events, and only a few studies report measurements on a yearly basis (Genberg et al., 2011; Gilardoni et al., 2011; Zotter et al., 2014b; Zhang et al., 2016, 2017; Dusek et al., 2017). Here, for a subset of $33 \mathrm{PM}_{10}$ filters from the year 2014, we present yearly contributions of $\mathrm{OC}_{\mathrm{nf}}, \mathrm{OC}_{\mathrm{f}}, \mathrm{EC}_{\mathrm{nf}}$ and $\mathrm{EC}_{\mathrm{f}}$.

Overall the total carbon concentrations followed a yearly pattern mainly caused by the shallow planetary boundary layer and the enhanced biomass burning activity during winter, with $\mathrm{OC}$ reaching on average $( \pm 1$ standard deviation) $9.4 \pm 4.5$ and EC $2.6 \pm 1.5 \mu \mathrm{g} \mathrm{m}^{-3}$ (Fig. 2a). During the rest of the year, TC remained rather stable with much lower concentrations $\left(\mathrm{OC}_{\mathrm{avg}}=3.7 \pm 1.9\right.$ and $\left.\mathrm{EC}_{\text {avg }}=0.8 \pm 0.7 \mu \mathrm{g} \mathrm{m}^{-3}\right) .{ }^{14} \mathrm{C}$ results indicate that nonfossil sources prevail over the fossil ones in Magadino. More specifically, we found that in winter on average $f_{\mathrm{NF}, \mathrm{OC}}=0.9 \pm 0.1$ and $f_{\mathrm{NF}, \mathrm{EC}}=0.5 \pm 0.1$, which is in 

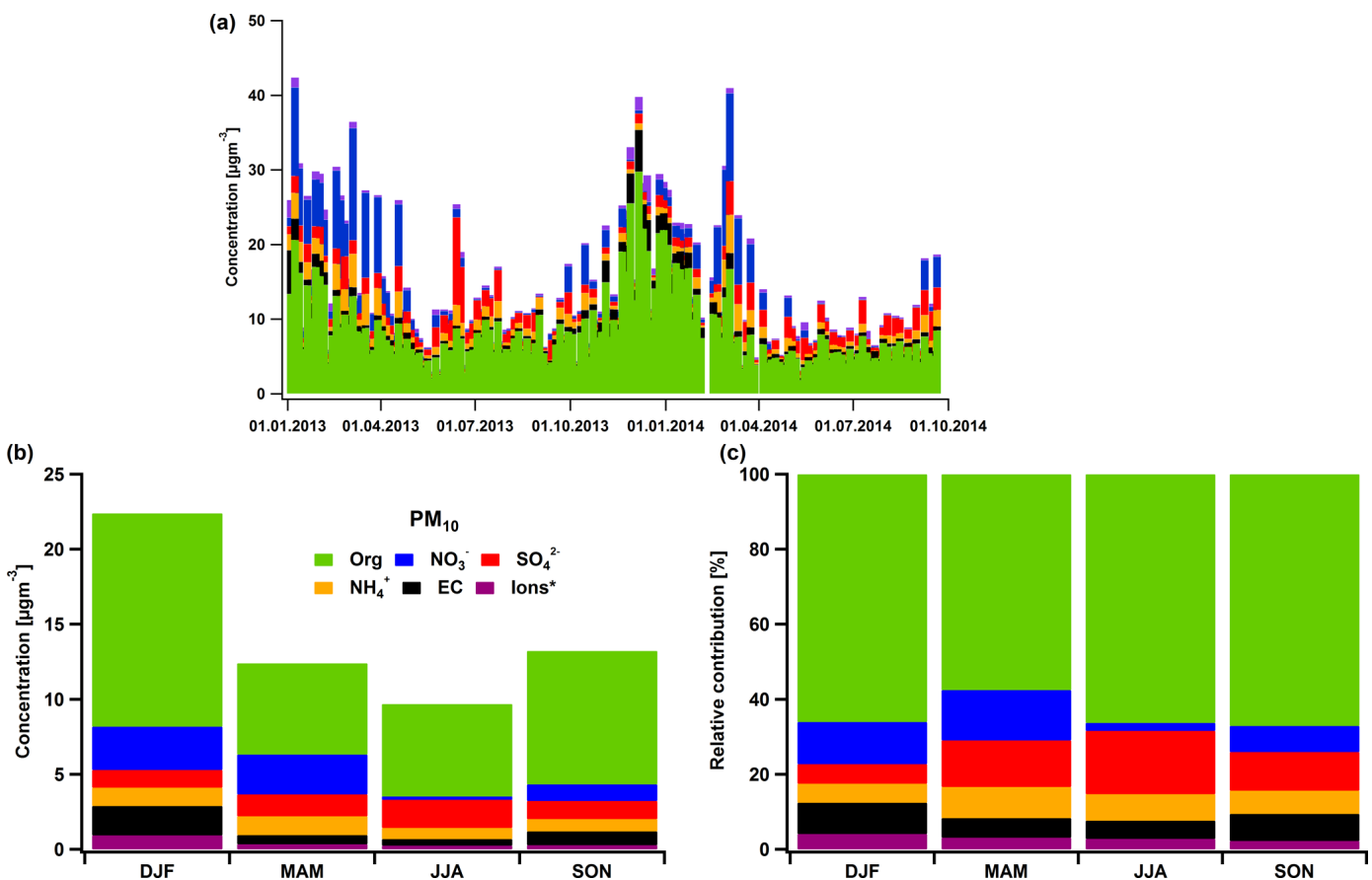

Figure 1. Concentrations of OM, EC and major ionic species for the years 2013 and 2014 (a), their seasonal concentrations (b) and relative contributions to the total measured mass within the particulate matter $\left(\mathrm{PM}_{10}\right)$ (c). The sum of the ions $\mathrm{Na}^{+}, \mathrm{K}^{+}, \mathrm{Mg}^{2+}, \mathrm{Ca}^{2+}$ and $\mathrm{Cl}^{-}$are included in the indication "Ions*".
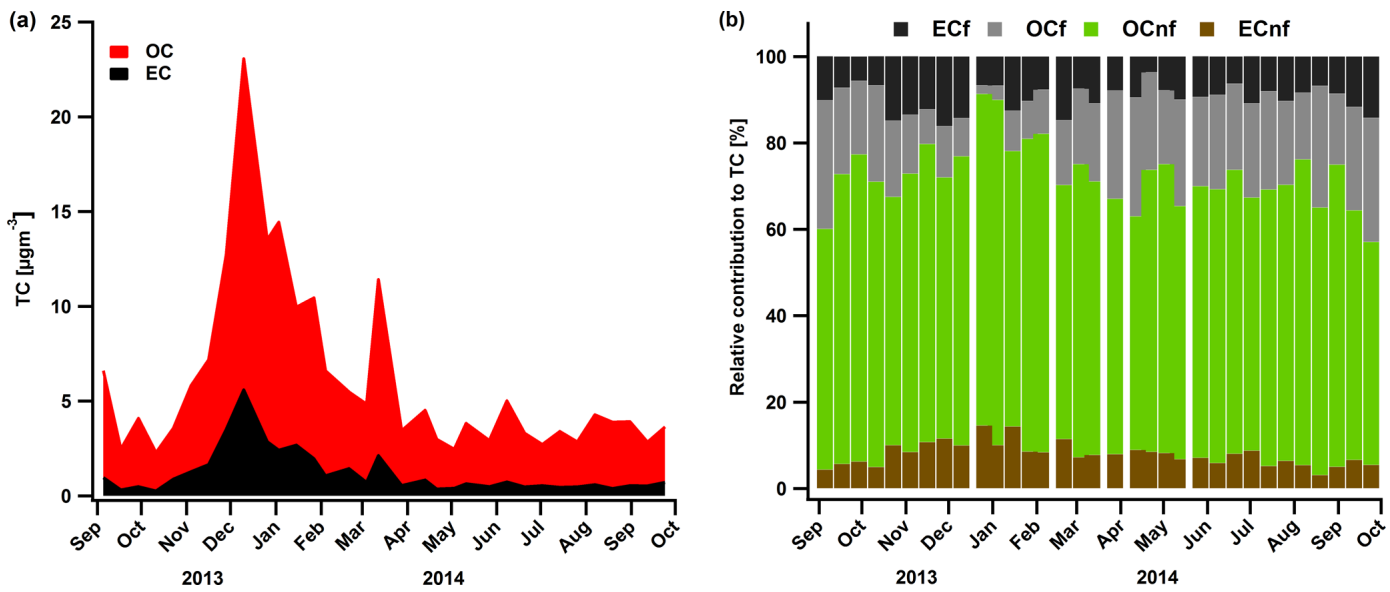

Figure 2. Time series of $\mathrm{OC}$ and $\mathrm{EC}$ (a) concentrations in $\mathrm{PM}_{10} \cdot{ }^{14} \mathrm{C}$ analysis results with the relative contributions of EC fossil, OC fossil, OC non-fossil and EC non-fossil to the TC (b).

agreement with the reported fractions by Zotter et al., 2014b $\left(f_{\mathrm{NF}, \mathrm{OC}}=0.8 \pm 0.1\right.$ and $\left.f_{\mathrm{NF}, \mathrm{EC}}=0.5 \pm 0.2\right)$. Table 1 summarizes the $f_{N F}$ per fraction season wise.

$\mathrm{OC}_{\mathrm{nf}}$ was the dominant part of TC throughout the year with contributions of up to $80 \%$ in winter and $71 \%$ in summer (Fig. 2b) and average concentrations of $8.5 \pm 4.2$ and $2.4 \pm 0.6 \mu \mathrm{g} \mathrm{m}^{-3}$ in winter and summer, respectively (Fig. 3b). Such high contributions in winter strongly indicate that biomass burning (BB) from residential heating is the main source of carbonaceous aerosols in this region, similar to previous reports (Jaffrezo et al., 2005; Puxbaum et al., 2007; Sandradewi et al., 2008; Favez et al., 2010; Zotter et al., 2014b). The coefficient of determination $R^{2}$ between $\mathrm{OC}_{\mathrm{nf}}$ and levoglucosan, a characteristic marker for BB, was 0.92 (Fig. S7a), and the slope $\left(\mathrm{OC}_{\mathrm{nf}} /\right.$ levoglucosan $\left.=4.8 \pm 0.3\right)$ lies within the reported range by Zotter et al. (2014b) for Magadino (which was $6.9 \pm 2.6)$.

The concentration of $\mathrm{EC}_{\mathrm{nf}}$ was significantly higher in winter (average $1.3 \pm 0.7 \mu \mathrm{g} \mathrm{m}^{-3}$ ) compared to the rest of 

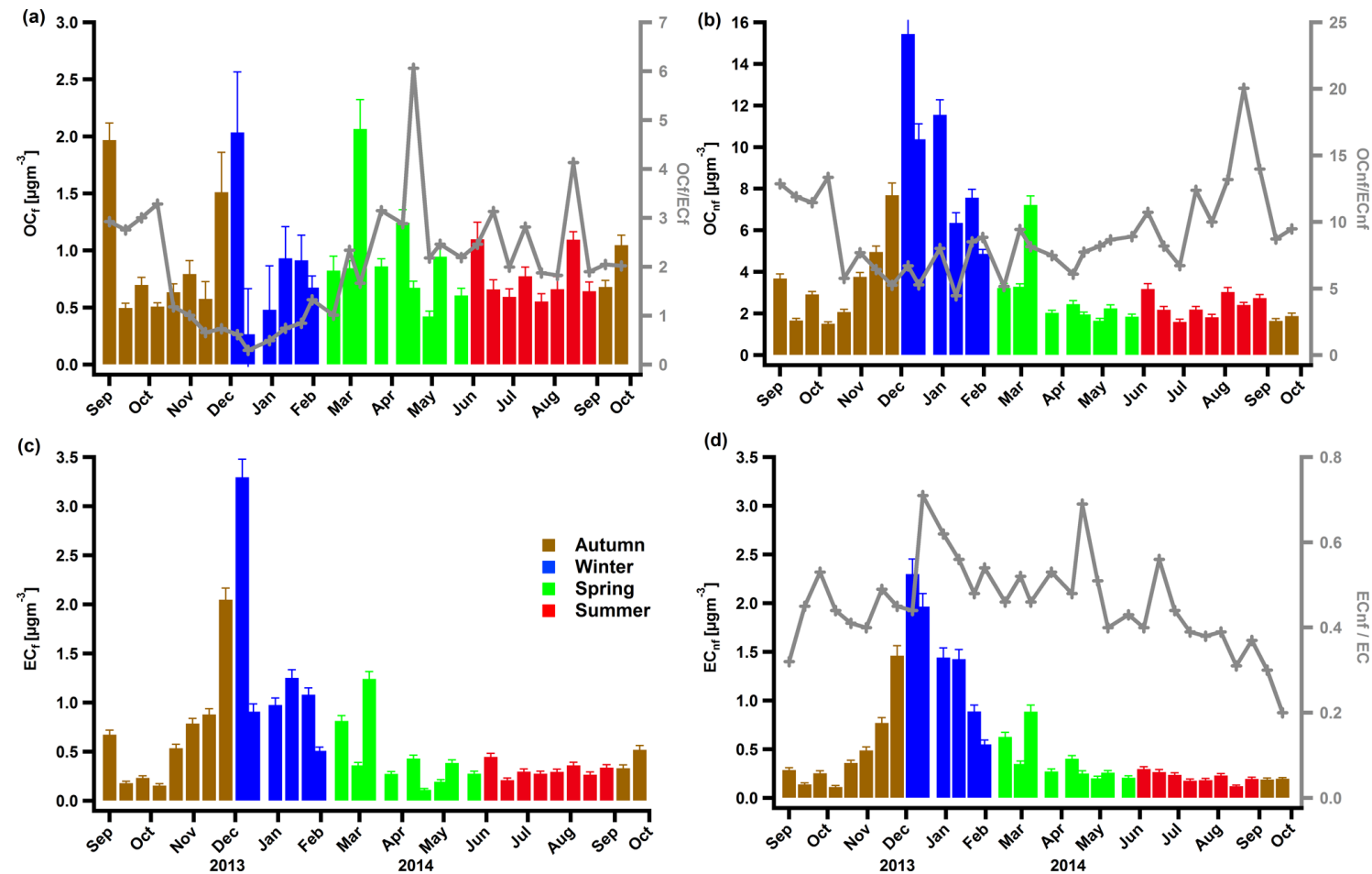

Figure 3. Concentrations in $\mathrm{PM}_{10}$ of $\mathrm{OC}_{\mathrm{f}}(\mathbf{a}), \mathrm{OC}_{\mathrm{nf}}(\mathbf{b}), \mathrm{EC}_{\mathrm{f}}(\mathbf{c})$ and $\mathrm{EC}_{\mathrm{nf}}(\mathbf{d})$ colour-coded by seasons. The ratios $\mathrm{OC}_{\mathrm{f}} / \mathrm{EC}_{\mathrm{f}}, \mathrm{OC}_{\mathrm{nf}} / \mathrm{EC}_{\mathrm{nf}}$, and $\mathrm{EC}_{\mathrm{nf}} / \mathrm{EC}$ are also displayed in (a), (b) and (d), respectively.

Table 1. Median OC and EC non-fossil fractions per season in $\mathrm{PM}_{10}$ with interquartile range.

\begin{tabular}{cccc|ccc|ccc|cccc}
\hline & \multicolumn{3}{c}{ Autumn } & \multicolumn{3}{c|}{ Winter } & \multicolumn{3}{c}{ Spring } & \multicolumn{3}{c}{ Summer } \\
\cline { 2 - 13 } & $Q_{25}$ & $Q_{50}$ & $Q_{75}$ & $Q_{25}$ & $Q_{50}$ & $Q_{75}$ & $Q_{25}$ & $Q_{50}$ & $Q_{75}$ & $Q_{25}$ & $Q_{50}$ & $Q_{75}$ \\
\hline$f_{\text {NF, OC }}$ & 0.71 & 0.77 & 0.83 & 0.87 & 0.88 & 0.93 & 0.70 & 0.75 & 0.79 & 0.73 & 0.76 & 0.79 \\
$f_{\text {NF,EC }}$ & 0.36 & 0.41 & 0.44 & 0.44 & 0.52 & 0.56 & 0.42 & 0.49 & 0.51 & 0.38 & 0.39 & 0.42 \\
\hline
\end{tabular}

the year (spring average: $0.4 \pm 0.2 \mu \mathrm{g} \mathrm{m}^{-3}$, summer average: $0.21 \pm 0.06 \mu \mathrm{g} \mathrm{m}^{-3}$, autumn average: $0.43 \pm 0.41 \mu \mathrm{g} \mathrm{m}^{-3}$ ) (Fig. 3d). $\mathrm{EC}_{\mathrm{nf}}$ is considered to originate solely from $\mathrm{BB}$, for instance from residential wood burning in winter. This assumption is supported by the very high correlation $\left(R^{2}=0.95\right)$ with levoglucosan (Fig. S7b) and the slope $\left(\mathrm{EC}_{\mathrm{nf}} /\right.$ levoglucosan $\left.=0.82 \pm 0.03\right)$ which is also in agreement with the literature (Zotter et al., 2014b; Herich et al., 2014).

The strong correlation between $\mathrm{OC}_{\mathrm{nf}}$ and $\mathrm{EC}_{\mathrm{nf}}$, driven mainly by the winter data points, supports the fact that $\mathrm{OC}_{\mathrm{nf}}$ is mostly from biomass burning in winter (Fig. S6a). In late spring, summer and early autumn, the contribution of $\mathrm{EC}_{\mathrm{nf}}$ decreased significantly (on average to $0.23 \pm 0.07 \mu \mathrm{g} \mathrm{m}^{-3}$ ). The low correlation of $\mathrm{OC}_{\mathrm{nf}}$ and $\mathrm{EC}_{\mathrm{nf}}$ during this period (Fig. S6a), in combination with the increase in the $\mathrm{OC}_{\mathrm{nf}} / \mathrm{EC}_{\mathrm{nf}}$ ratio in summer (Fig. 3b), suggests that a part of the secondary $\mathrm{OC}_{\mathrm{nf}}$ originates from non-combustion sources, e.g. biogenic/natural sources.
In total, the relative contribution of the fossil fraction to the TC was $27 \%$. Excluding winter, $\mathrm{EC}_{\mathrm{f}}$ exhibited slightly higher concentrations than $\mathrm{EC}_{\mathrm{nf}}$ (Fig. $3 \mathrm{c}$ and d). The average concentrations of $\mathrm{EC}_{\mathrm{f}}$ were $1.26 \pm 0.93,0.41 \pm 0.35$, $0.31 \pm 0.07$ and $0.63 \pm 0.56 \mu \mathrm{g} \mathrm{m}^{-3}$ for winter, spring, summer and autumn, respectively (Fig. 3c). The increase in $\mathrm{EC}_{\mathrm{f}}$ witnessed in winter could be mainly attributed to the shallower planetary boundary layer (PBL) rather than to an increase in the emissions (Fig. S8a). The sources of $\mathrm{EC}_{\mathrm{f}}$ in the coarse $\left(\mathrm{PM}_{10}-\mathrm{PM}_{2.5}\right)$ size fraction are typically related to resuspension of abrasion products of vehicle tires or brake wear (Bukowieki et al., 2010; Zhang et al, 2013). The fine part of $\mathrm{EC}_{\mathrm{f}}$ is due to fossil fuel burning, here mostly due to traffic exhaust emissions. It is significantly correlated with $\mathrm{NO}_{x}$ (Fig. S8b) and the $\mathrm{EC}_{\mathrm{f}} / \mathrm{NO}_{x}=0.020$ ratio lies within the reported slopes (Zotter et al., 2014b, and references therein).

The contribution of $\mathrm{OC}_{\mathrm{f}}$ to $\mathrm{TC}$ decreased during winter $(8 \%)$ but remained roughly stable throughout the rest of the year (22\% in spring, $21 \%$ in summer and $19 \%$ in 


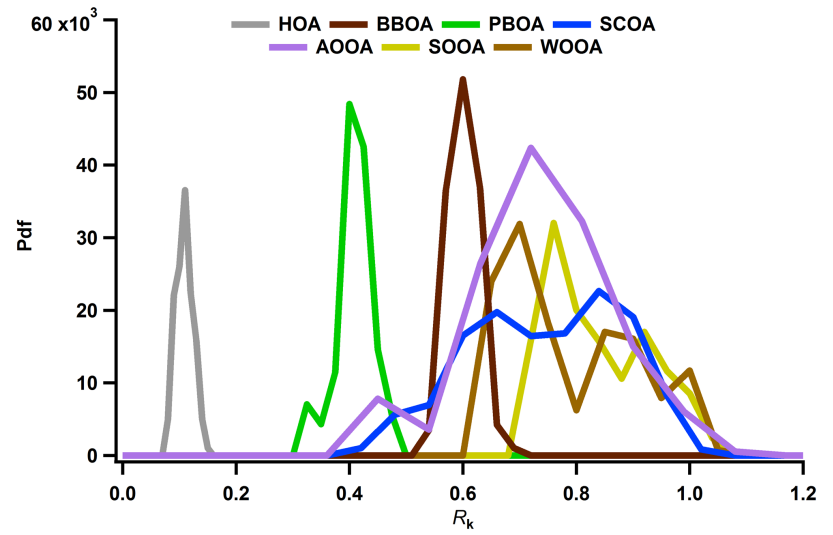

Figure 4. Probability density functions of factor recoveries: hydrocarbon-like OA (HOA) in grey, biomass burning OA (BBOA) in dark brown, sulfur-containing OA (SCOA) in blue, primary biological OA (PBOA) in green, anthropogenic oxygenated OA (AOOA) in purple, summer oxygenated OA (SOOA) in yellow and winter oxygenated OA (WOOA) in light brown.

Table 2. Variability of OM / OC and factor recoveries.

\begin{tabular}{llll|lll}
\hline & \multicolumn{3}{c|}{ OM / OC } & \multicolumn{3}{c}{$R_{k}$} \\
\cline { 2 - 7 } & $Q_{25}$ & $Q_{50}$ & $Q_{75}$ & $Q_{25}$ & $Q_{50}$ & $Q_{75}$ \\
\hline HOA & 1.32 & 1.33 & 1.36 & 0.10 & 0.11 & 0.13 \\
BBOA & 1.76 & 1.77 & 1.78 & 0.60 & 0.61 & 0.63 \\
SCOA & 2.03 & 2.16 & 2.20 & 0.68 & 0.81 & 0.89 \\
PBOA & 1.74 & 1.76 & 1.82 & 0.41 & 0.42 & 0.44 \\
AOOA & 2.12 & 2.14 & 2.16 & 0.72 & 0.79 & 0.87 \\
SOOA & 1.66 & 1.67 & 1.68 & 0.78 & 0.84 & 0.94 \\
WOOA & 1.76 & 1.79 & 1.83 & 0.72 & 0.78 & 0.92 \\
\hline
\end{tabular}

autumn, Fig. 2b) with average concentrations $0.87 \pm 0.30$, $0.96 \pm 0.12,0.89 \pm 0.14$ and $0.76 \pm 0.10 \mu \mathrm{g} \mathrm{m}^{-3}$ for winter, spring, summer and autumn, respectively (Fig. 3a). The low correlation overall observed between $\mathrm{OC}_{\mathrm{f}}$ and $\mathrm{EC}_{\mathrm{f}}$ (Fig. S6b) may indicate that a fraction of $\mathrm{OC}_{\mathrm{f}}$ is not directly emitted but formed as secondary OC (SOC) from fossil-fuel-related emissions (e.g. traffic). This is supported by low $\mathrm{OC}_{\mathrm{f}} / \mathrm{EC}_{\mathrm{f}}$ ratios in winter (on average $0.7 \pm 0.3$ ) and much higher values in spring and summer (on average $2.7 \pm 1.1$ ) (Fig. 3a). The low ratios are consistent with tunnel measurement studies (Li et al., 2016; Chirico et al., 2011; El Haddad et al., 2009) and the increase in $\mathrm{OC}_{\mathrm{f}} / \mathrm{EC}_{\mathrm{f}}$ in spring and summer above these values is an indication of anthropogenic SOA formation. We also note that fossil SOA may be formed by other sources besides traffic. A recent study revealed that fossil SOA is produced by the oxidation of volatile chemical products coming from petrochemical sources (McDonald et al., 2018).

\subsection{Offline AMS analysis results: factor interpretation}

In this section, we will interpret the PMF outputs. The factor recoveries for all factors, $R_{k}$, determined as described in Sect. 3.3, are shown in Fig. 4. Factor mass spectra are displayed in Fig. 5. The contribution of the different factors to $\mathrm{OA}$ is presented in Fig. 6. In addition, for some cases we will discuss the factor contribution to OC to check the consistency of our results with previous literature reports. Recovery values determined and used in this study will also be compared for each factor to previous values. Median values of the recoveries as well as the OM / OC ratios with their interquartile range are compiled in Table 2 . The $R_{k}$ values were in general consistent with previous reports (Daellenbach et al., 2016, 2017; Bozzetti et al., 2016). Here we report for the first time the recoveries of each SOA factor individually which were in agreement with the ones reported by Daellenbach et al. (2016). The consistency of the recovery results with not only previous offline AMS/PMF studies but also with online AMS measurements (Xu et al., 2017) points out that this method is rather robust and universal for different datasets.

Hydrocarbon-like OA (HOA), typically associated with traffic emissions, was constrained using the reference HOA high-resolution profile from Crippa et al. (2013). The resulting factor profile (Fig. 5) exhibited a low OM / OC (Table 2) and the time series followed the one from $\mathrm{NO}_{x}$ (Fig. 6). As the offline AMS technique requires water-extracted samples, it is expected that HOA, which mostly contains waterinsoluble material, will be poorly represented. This is also shown by the low recovery $R_{\mathrm{HOA}}$,median which was estimated to be $0.11\left(Q_{25}=0.10\right.$ and $\left.Q_{75}=0.13\right)$ as reported in Daellenbach et al. (2016) (Fig. 4). Therefore, the correlation between HOA and $\mathrm{NO}_{x}$ was weak (Fig. S9). However, the $\mathrm{HOA} / \mathrm{NO}_{x}$ ratio was 0.017 for $\mathrm{PM}_{10}$ and 0.008 for $\mathrm{PM}_{2.5}$ and these values are consistent with already reported ones in the literature (Daellenbach et al., 2017; Lanz et al., 2007). In addition, the $\mathrm{HOC}$ time series followed a similar yearly cycle as $\mathrm{EC}_{\mathrm{f}}$ (Fig. S10a) and the $\mathrm{HOC} / \mathrm{OC}_{\mathrm{f}}$ ratio was $0.37 \pm 0.12$ (Fig. S10b), in agreement with Zotter et al. (2014a).

Biomass burning OA (BBOA) was identified by its significant contributions of the oxygenated fragments $\mathrm{C}_{2} \mathrm{H}_{4} \mathrm{O}_{2}^{+}$ (at $m / z$ 60) and $\mathrm{C}_{3} \mathrm{H}_{5} \mathrm{O}_{2}^{+}$(at $m / z$ 73), common markers for wood burning formed by fragmentation of anhydrous sugars (Alfarra et al., 2007) (Fig. 5). It was also identified by its distinct seasonal variation which exhibited exclusively high concentrations in winter, reaching up to $20.0 \pm 0.7 \mu \mathrm{g} \mathrm{m}^{-3}$ for $\mathrm{PM}_{10}$ in December 2013 and $12.3 \pm 0.5 \mu \mathrm{g} \mathrm{m}^{-3}$ for $\mathrm{PM}_{2.5}$ in January 2014 (Fig. 6). The median value for the OM / OC ratio was 1.8 and the $R_{\mathrm{BBOA}}$ was consistent with the low end of the reported one by Daellenbach et al. (2016) (Table 2). The identification of this factor as BBOA was further confirmed by its remarkable correlation with levoglucosan. Similar to levoglucosan, this factor did not exhibit a significant difference between $\mathrm{PM}_{2.5}$ and $\mathrm{PM}_{10}$ concentrations (Fig. S5a), suggesting that most of these particles are 


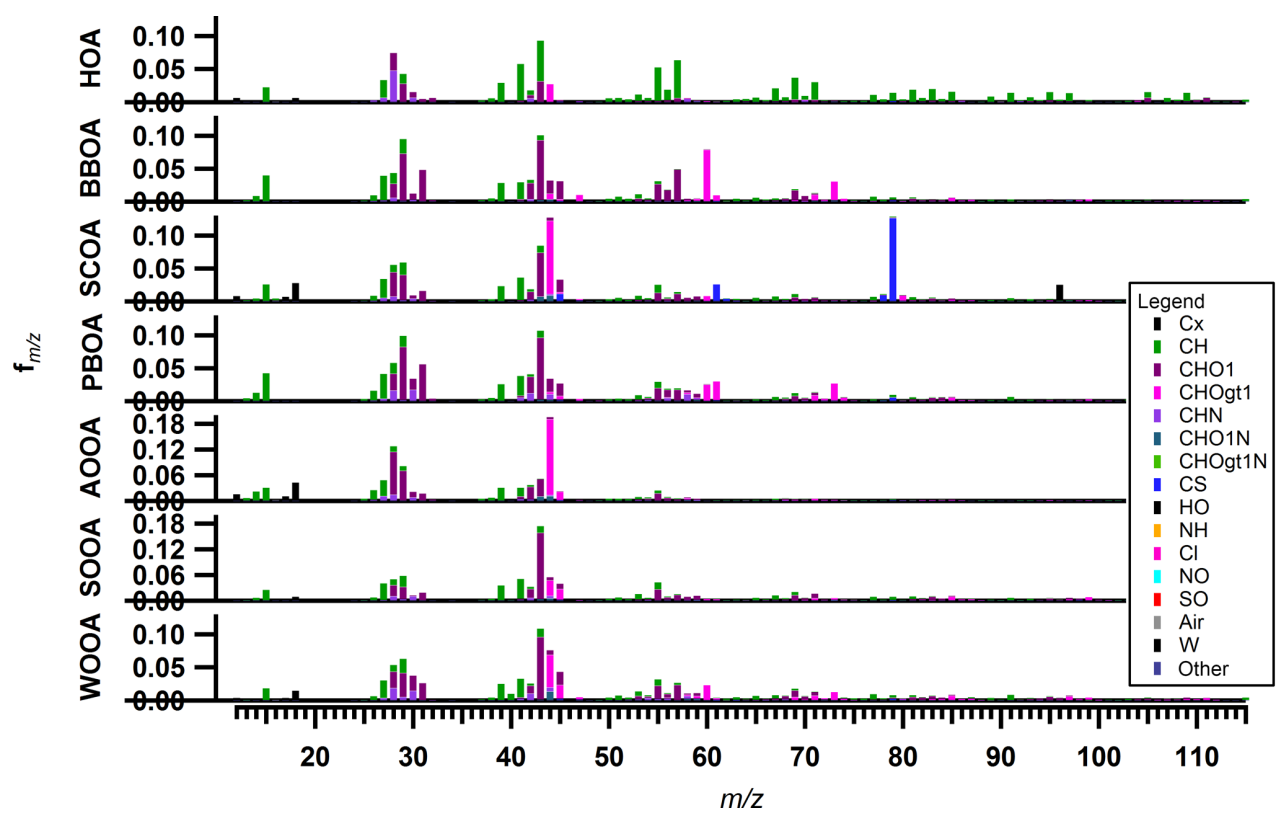

Figure 5. Offline AMS/PMF (ME-2) factor profiles: hydrocarbon-like OA (HOA), biomass burning OA (BBOA), sulfur-containing OA (SCOA), primary biological OA (PBOA), anthropogenic oxygenated OA (AOOA), summer oxygenated OA (SOOA) and winter oxygenated OA (WOOA).

present in the fine mode, consistent with previous observations (Levin et al., 2010b). The BBOA/levoglucosan ratio was 7.1 for $\mathrm{PM}_{10}$ and 5.8 for $\mathrm{PM}_{2.5}$, which falls into the range reported by Daellenbach et al. (2017) and was also consistent with the ratio reported by Bozzetti et al. (2016). The difference of BBOA/levoglucosan for the two size fractions is due to four samples in $\mathrm{BBOA} \mathrm{PM}_{10}$ with high concentrations. Lastly, BBOC showed a strong correlation with $\mathrm{EC}_{\mathrm{nf}}$, with a slope of 4.9 (Fig. $7 \mathrm{~b}$ ) which fell within the range of the compiled $\mathrm{EC}_{\mathrm{nf}} / \mathrm{BBOC}$ ratios in Ulevicius et al. (2016).

Sulfur-containing OA (SCOA) was identified by its spectral fingerprint which is described by a high contribution of the fragment $\mathrm{CH}_{3} \mathrm{SO}_{2}^{+}$(at $m / z$ 79) (Fig. 5) and high OM / OC ratio (Table 2). The $R_{\mathrm{SCOA}}$ (Fig. 4, Table 2) showed a much broader distribution than the rest of the primary OC recoveries yet more limited towards the strongly watersoluble fractions compared to Daellenbach et al. (2017). SCOA concentrations were higher in the coarse fraction compared to $\mathrm{PM}_{2.5}$ (Figs. 6 and 7c, S5) and exhibited higher concentrations during autumn and winter compared to summer (Table 3). A similar profile had previously been linked to a marine origin by Crippa et al. (2013) in Paris; however, Daellenbach et al. (2017) found that SCOA in Switzerland was rather a primary locally emitted source with no marine origin due to its anti-correlation with methane sulfonic acid (MSA). Here we confirm that SCOA did not follow the MSA time series (Fig. S11) but rather the time series of $\mathrm{NO}_{x}$. These observations suggest that this factor is connected to a primary coarse particle episodic source related to traffic.
Primary biological OA (PBOA) exhibited significant contributions from the fragment $\mathrm{C}_{2} \mathrm{H}_{5} \mathrm{O}_{2}^{+}$(part of $\mathrm{m} / z \quad 61$ ) (Fig. 5) and was more enhanced in summer and spring (Fig. 6). The $R_{\text {PBOA }}$ (Fig. 4, Table 2) met the high end of $R_{\text {PBOA }}$ in Bozzetti et al. (2016). PBOA appeared mostly in the coarse mode (Table 3, Fig. S5). The mass spectral features, the seasonality and coarse contribution suggested the biological nature of this factor possibly including plant debris. Additional support of this interpretation is provided by the correlation of PBOA with cellulose (Fig. 7d), a polymer mostly found in the cell wall of plants. The correlation improved if only data from summer and spring were considered. The outliers here were the late autumn and winter points when BBOA was more important and PBOA could not as easily be separated by the PMF technique.

One out of the three oxygenated OAs (OOA) was identified as a highly oxidized factor, due to the significant contribution of the fragment $\mathrm{CO}_{2}^{+}$(Fig. 5) and the high $\mathrm{OM} / \mathrm{OC}$ ratio (Table 2) which was consistent with the reported OM / OC ratio by Turpin et al. (2001) for nonurban aerosols. This factor peaked mainly in winter and spring and the $\mathrm{PM}_{2.5}$ size fraction exhibited higher concentrations during this period compared to the coarse size fraction (Table 3, Fig. 6). The water solubility of this oxygenated factor was high (Fig. 4, Table 2), which is consistent with the literature values (Daellenbach et al., 2016, 2017) that refer to the sum of all oxygenated factors, as well as with reported water-soluble fractions for highly oxidized compounds (Xu et al., 2017). The yearly median concentration for $\mathrm{PM}_{10}$ was $0.97 \mu \mathrm{g} \mathrm{m}^{-3}\left(Q_{25}=0.86\right.$ and $Q_{75}=$ 


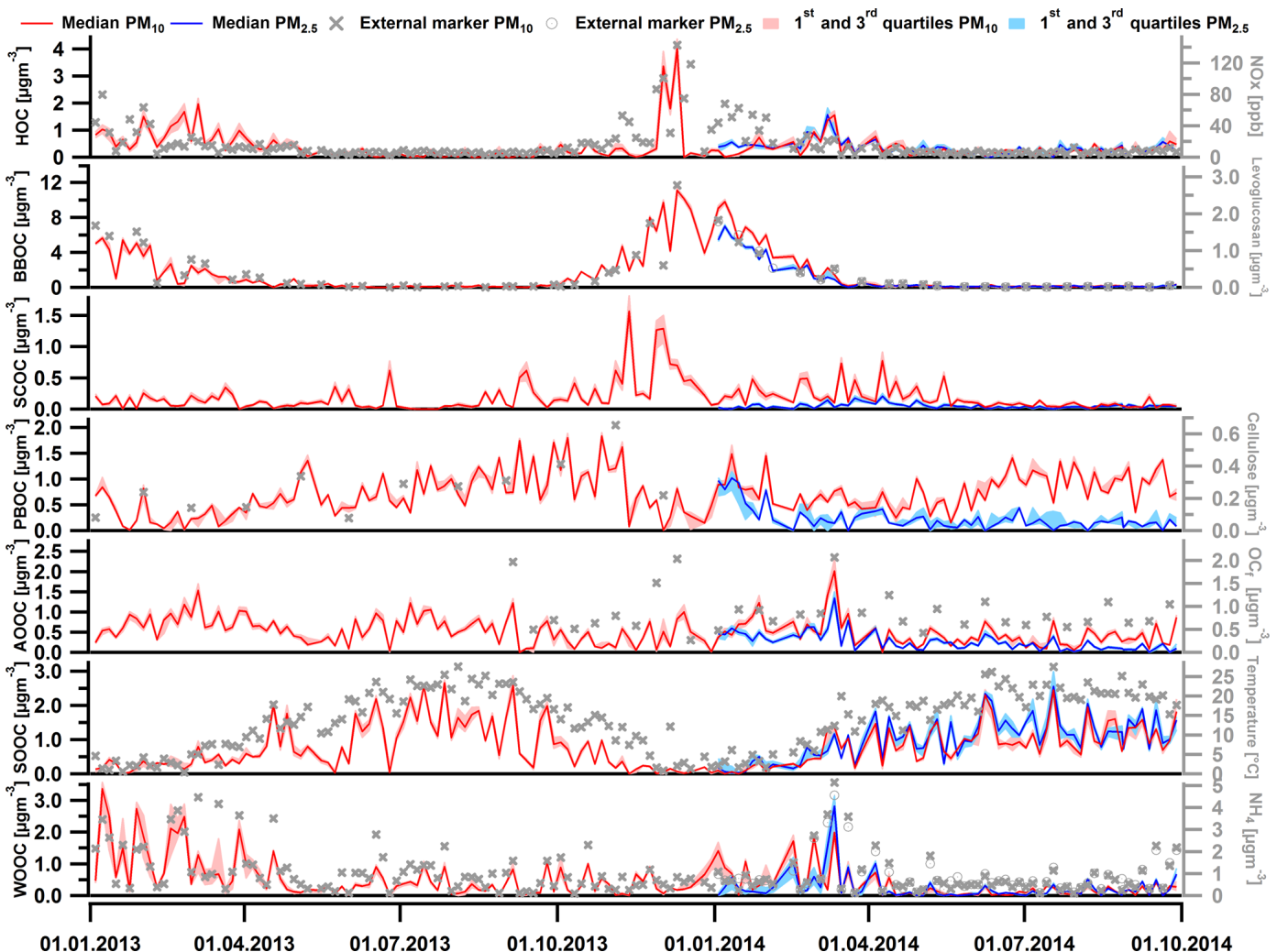

Figure 6. Factor (in red for $\mathrm{PM}_{10}$ and blue for $\mathrm{PM}_{2.5}$ ) and external marker (in grey markers) time series for the two size fractions: $\mathrm{HOC}$ and $\mathrm{NO}_{x}, \mathrm{BBOC}$ and levoglucosan, SCOC, PBOC and cellulose, AOOC and $\mathrm{OC}_{\mathrm{f}}, \mathrm{SOOC}$ and temperature, and $\mathrm{WOOC}$ and $\mathrm{NH}_{4}^{+}$. $\mathrm{Note}$ that here, different from Fig. 5, the factors are quantified according to their carbon mass concentration, with HOC, BBOC, SCOC, PBOC, AOOC, SOOC, and WOOC referring to hydrocarbon-like organic carbon (OC), biomass burning OC, sulfur-containing OC, primary biological OC, anthropogenic oxygenated OC, summer oxygenated OC, and winter oxygenated OC, respectively.

$1.09 \mu \mathrm{g} \mathrm{m}^{-3}$ ), which accounts for approximately $13 \%$ of the total OA. Out of all the possible correlations with external markers, this factor correlated best with $\mathrm{OC}_{\mathrm{f}}(\mathrm{Fig} .7 \mathrm{e})$; therefore, we chose to name it anthropogenic OOA (AOOA) (see also discussion in Sect. 4.4.2). Both AOOC and $\mathrm{OC}_{\mathrm{f}}$ followed very similar annual cycles (Fig. S12) with average AOOC $/ \mathrm{OC}_{\mathrm{f}}=0.97 \pm 2.49$. This observation along with the increase in $\mathrm{OC}_{\mathrm{f}} / \mathrm{EC}_{\mathrm{f}}$ as already discussed in Sect. 4.2 could indicate that this factor is linked to secondary organic aerosol from traffic emissions or to transported air masses from industrialized areas. It may also be connected to the oxidation of volatile chemical products such as pesticides, coatings, printing inks or cleaning agents (McDonald et al., 2018). Further discussion about AOOC can be found in Sect. 4.4.

Summer oxygenated OA (SOOA) was mainly identified by the high contribution of the fragment $\mathrm{C}_{2} \mathrm{H}_{3} \mathrm{O}^{+}(\mathrm{m} / \mathrm{z}, 43)$ (Fig. 5) $\left(f \mathrm{C}_{2} \mathrm{H}_{3} \mathrm{O}^{+}=0.15\right)$ as well as its seasonal behaviour (Fig. 6). Like all the oxygenated OA factors, it was highly water soluble (Fig. 4, Table 2). The highest concentrations were witnessed in July with values of $4.4 \mu \mathrm{gm}^{-3}$ for $\mathrm{PM}_{10}$ in 2013 and $4.3 \mu \mathrm{gm}^{-3}$ for $\mathrm{PM}_{2.5}$ in 2014. The bulk contribution of this factor was present in the $\mathrm{PM}_{2.5}$ fraction (Table 3,
Fig. S5). The seasonal variability of SOOA followed the daily temperature average (Fig. 6). In fact, SOOA exponentially increased with temperature (Fig. 7f). Such behaviour was also observed in Daellenbach et al. (2017), where they connected this factor to the oxidation of terpene emissions and therefore to biogenic SOA formation. The exponential dependence of SOOA with temperature was also similar to the temperature dependence of the biogenic SOA concentrations from a Canadian terpene-rich forest, reported by Leaitch et al. (2011). A similar factor was identified with an online instrument in Zurich during summer 2011, where the semi-volatile OOA was mainly formed by biogenic sources as the high temperatures favour the biogenic emissions compared to the rest (Canonaco et al., 2015). Finally, the O / C ratio $(0.37)$ fell into the range of the reported $\mathrm{O} / \mathrm{C}$ ratios measured by chamber-generated SOA (Aiken et al., 2008), which was similar to biogenic SOA produced in flow tubes (Heaton et al., 2007).

Named after its seasonal behaviour (Daellenbach et al., 2017), the third oxygenated factor, winter oxygenated OA (WOOA), exhibited the highest concentrations during winter. WOOA mass spectrum exhibited elevated contributions of 

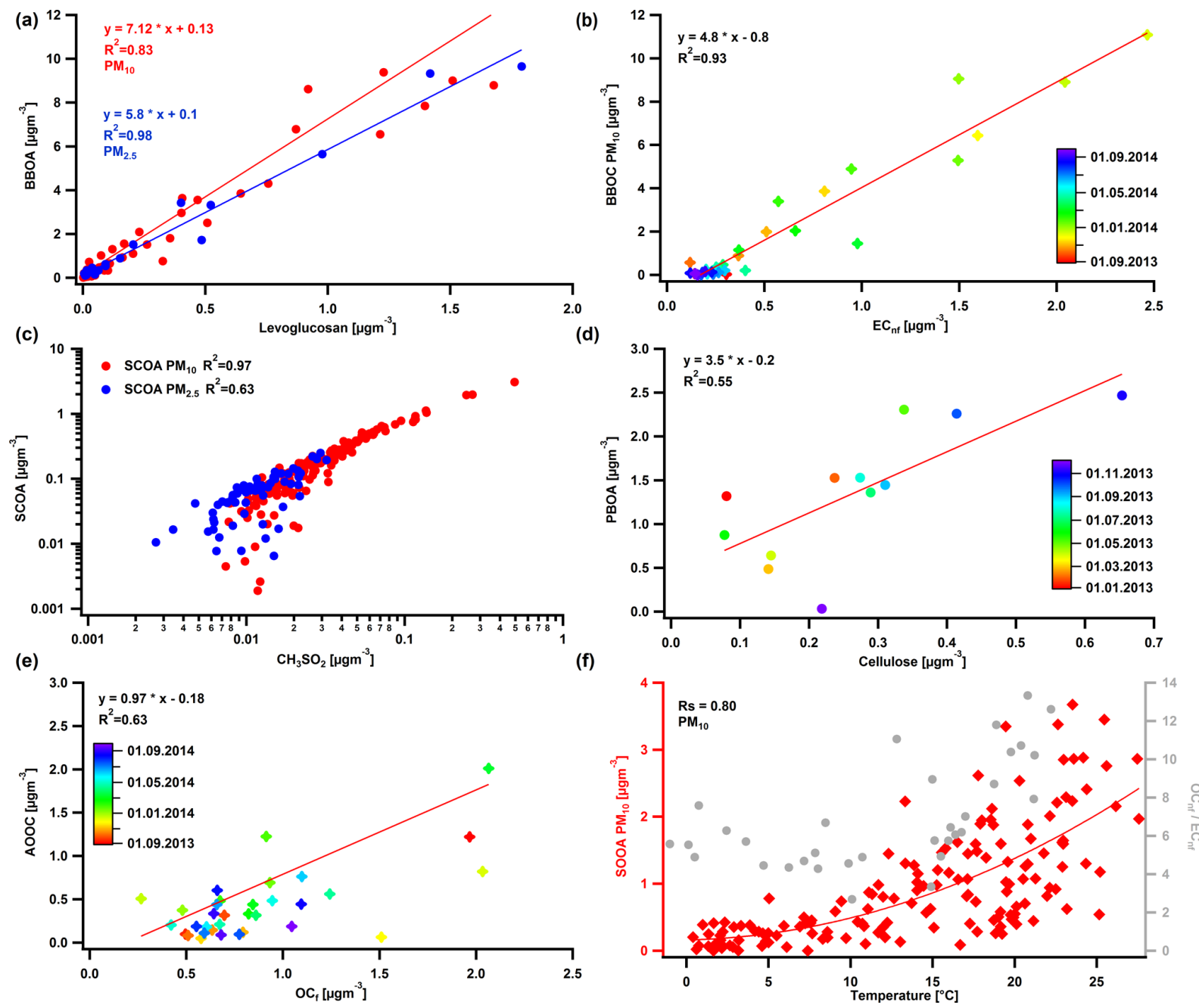

Figure 7. Correlations between $\mathrm{BBOA}$ and levoglucosan for the two size fractions (a), $\mathrm{BBOC}$ and $\mathrm{EC}_{\mathrm{nf}}$ for $\mathrm{PM}_{10}(\mathbf{b}), \mathrm{SCOA}_{\text {and }} \mathrm{CH}_{3} \mathrm{SO}_{2}^{+}$ for the two size fractions (c) (the regression lines show a linear relationship), PBOA and cellulose for $\mathrm{PM}_{10}(\mathbf{d}), \mathrm{AOOC}_{\text {and }} \mathrm{OC}$ (the regression fit was weighted by the standard deviation of $\mathrm{AOOC})(\mathbf{e})$, and $\mathrm{SOOA}$ and daily averaged temperature as $\mathrm{well}_{\mathrm{l}}$ as $\mathrm{OC}_{\mathrm{nf}} / \mathrm{EC}_{\mathrm{nf}}$ ratio and temperature for $\mathrm{PM}_{10}(\mathbf{f})$.

the fragment $\mathrm{C}_{2} \mathrm{H}_{3} \mathrm{O}^{+}$(Fig. 5), but lower compared to SOOA (for WOOA $f \mathrm{C}_{2} \mathrm{H}_{3} \mathrm{O}^{+}=0.11$ ). It also exhibited a slightly enhanced contribution of the fragment $\mathrm{C}_{2} \mathrm{H}_{4} \mathrm{O}_{2}^{+}$which can be an indication that this factor originated from aged biomass burning emissions. Moreover, a similar mass spectral pattern (peaks of fragments $\mathrm{C}_{3} \mathrm{H}_{3} \mathrm{O}^{+}, \mathrm{C}_{3} \mathrm{H}_{5} \mathrm{O}_{2}^{+}, \mathrm{C}_{4} \mathrm{H}_{5} \mathrm{O}_{2}^{+}$and $\mathrm{C}_{5} \mathrm{H}_{7} \mathrm{O}_{2}^{+}$at $m / z 55,73,85$ and 99 , respectively) to the one coming from oxygenated products from a wood-burning experiment (Bruns et al., 2015) was found. The recovery of this factor manifested high values (Table 2) and consisted mainly of fine-mode particles (Fig. S5). WOOA also correlated with $\mathrm{NH}_{4}^{+}$(Fig. S13), which is directly connected to the inorganic secondary ions $\mathrm{NO}_{3}^{-}$and $\mathrm{SO}_{4}^{2-}$.

\subsection{Coupling of offline AMS and ${ }^{14} \mathrm{C}$ analyses}

In this section of the paper we will show the combined results of AMS/PMF and radiocarbon analyses. The first part will elaborate on the technical aspect of the analysis by presenting the calculation of the contribution of each factor to the fossil OC. In the second part, a thorough description of each fossil and non-fossil major source will be given. The time series of each fossil and non-fossil fraction for the whole AMS dataset is illustrated in Fig. 10. Contributions of the primary and secondary $\mathrm{OC}$ to the total $\mathrm{OC}$ will be also discussed and shown in Fig. 11. 


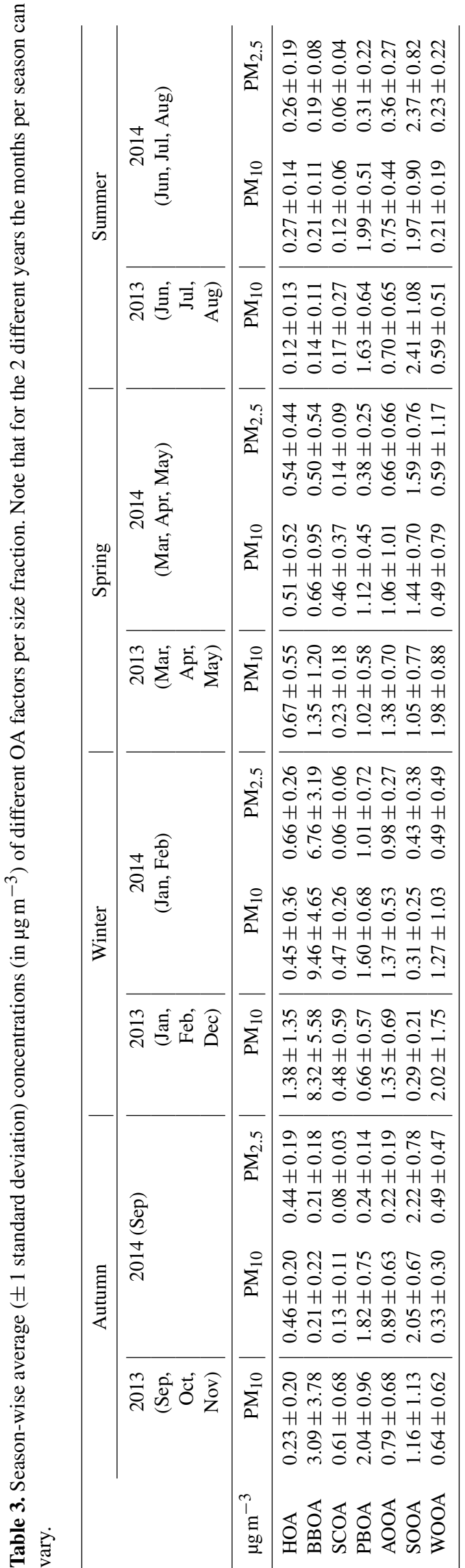

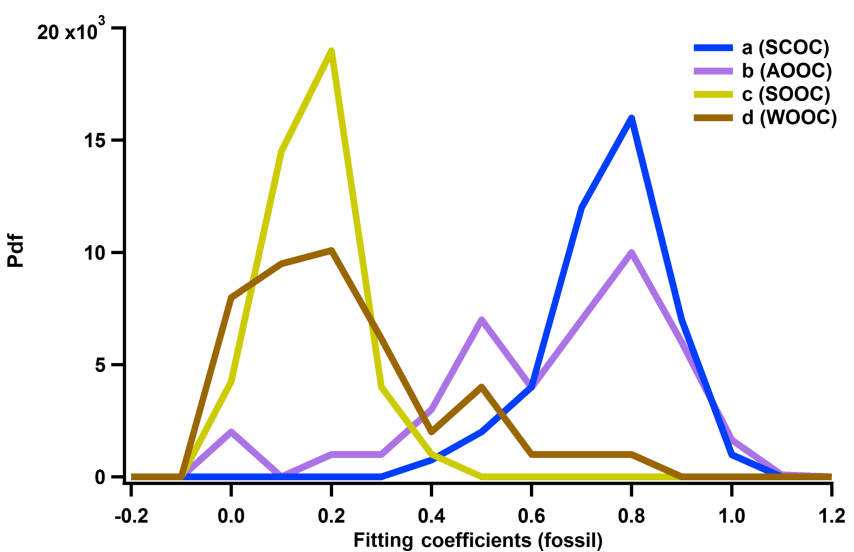

Figure 8. Probability density functions of the fitting coefficients of the relative fossil contributions: SCOC in blue, AOOC in purple, SOOC in yellow and WOOC in light brown.

\subsubsection{Calculation of fossil and non-fossil fraction per factor}

To combine the AMS/PMF with the ${ }^{14} \mathrm{C}$ results, the identified sources from AMS/PMF were divided into fossil and non-fossil fractions. HOC was fully assigned to fossil sources assuming that the percentage of biofuel content is negligible. BBOC and PBOC were considered totally nonfossil. To explore the fossil and non-fossil nature of the rest of the factors, we performed multilinear regression using Eq. (17):

$$
\begin{gathered}
\mathrm{OC}_{\mathrm{f}, i}-\mathrm{HOC}_{i}=a \cdot \mathrm{SCOC}_{i}+b \cdot \mathrm{AOOC}_{i} \\
\quad+c \cdot \mathrm{SOOC}_{i}+d \cdot \mathrm{WOOC}_{i},
\end{gathered}
$$

where $a, b, c$ and $\mathrm{d}$ are the fitting coefficients, weighted by the relative uncertainty of $\mathrm{OC}_{\mathrm{f}, i}-\mathrm{HOC}_{i}$. To investigate the stability of the solution, we obtained distributions of the fitting coefficients by performing 100 bootstrap runs where input data were randomly selected (Fig. 8). The median values (and first and third quartiles) were as follows: $a=0.81\left(Q_{25}=0.73, Q_{75}=0.88\right), b=0.77\left(Q_{25}=0.54\right.$, $\left.Q_{75}=0.85\right), c=0.21\left(Q_{25}=0.15, Q_{75}=0.26\right)$ and $d=$ $0.23\left(Q_{25}=0.13, Q_{75}=0.39\right)$.

We chose to apply the multilinear regression to the fossil fraction because for the non-fossil part, the errors related to fitting coefficients were very high and the dependences of the $\mathrm{OC}_{\mathrm{nf}}$ on the input factors were not statistically significant ( $p$ values $>0.1$ ).

To calculate the non-fossil part of each factor $k\left(k \mathrm{OC}_{\mathrm{nf}}\right)$, we used the following equation:

$k \mathrm{OC}_{\mathrm{nf}, i}=k \mathrm{OC}_{i}-k \mathrm{OC}_{\mathrm{f}, i}$.

This analysis suggests that the major fossil primary sources were HOC and SCOC $(81 \% \pm 11 \%$ fossil), while AOOC $(77 \% \pm 23 \%$ fossil) was the only major fossil secondary source. In terms of the non-fossil sources, the 
(a)

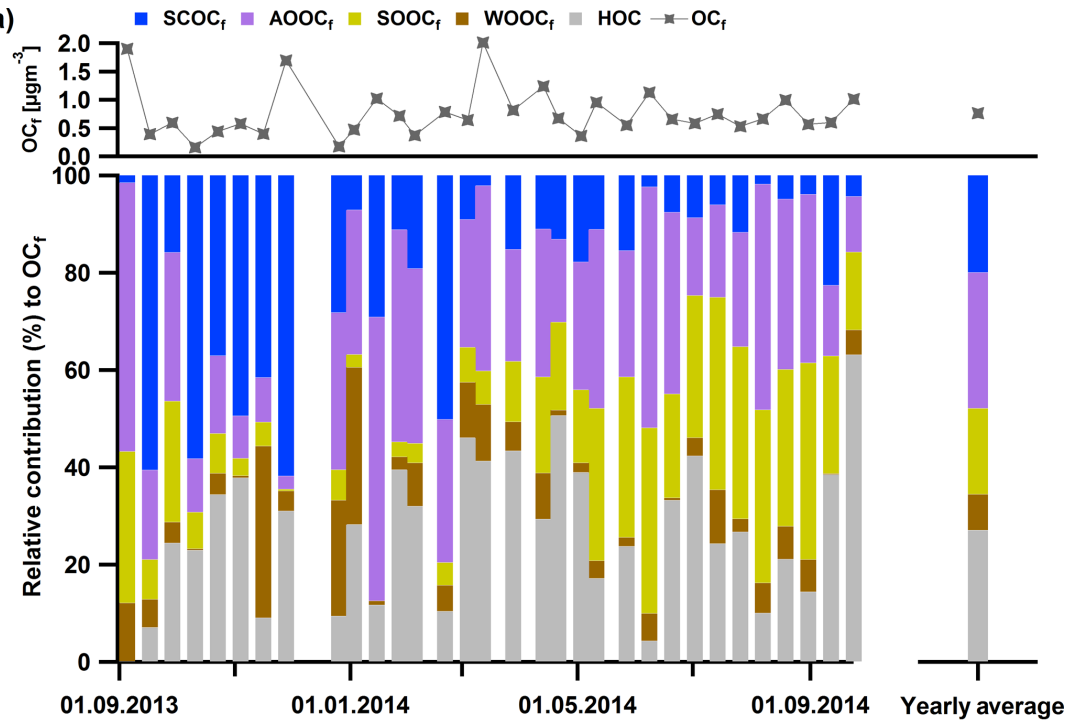

(b)

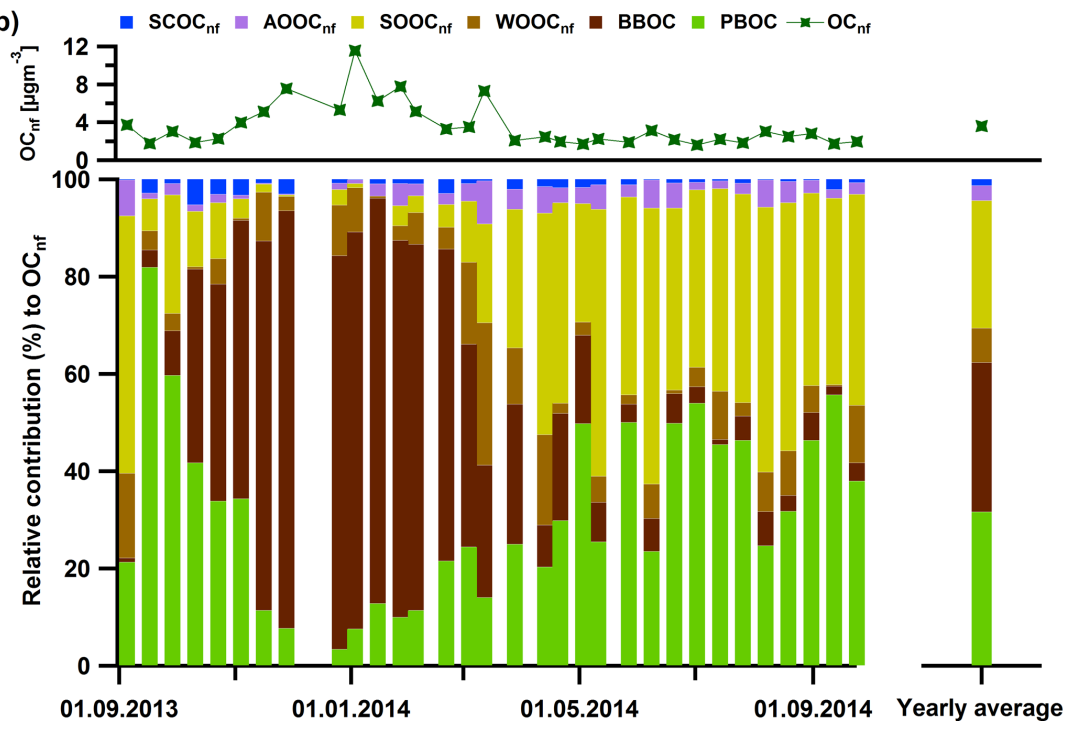

Figure 9. Relative contributions to the fossil OC per factor $\left(\mathrm{PM}_{10}\right)(\mathbf{a})$ and to the non-fossil OC per factor $\left(\mathrm{PM}_{10}\right)(\mathbf{b})$ : $\mathrm{BBOC}$ in dark brown, $\mathrm{SCOC}_{\mathrm{f}}$ and $\mathrm{SCOC}_{\mathrm{nf}}$ in blue, PBOC in green, $\mathrm{AOOC}_{\mathrm{f}}$ and $\mathrm{AOOC}_{\mathrm{nf}}$ in purple, $\mathrm{SOOC}_{\mathrm{f}}$ and $\mathrm{SOOC}_{\mathrm{nf}}$ in yellow, and $\mathrm{WOOC}_{\mathrm{f}}$ and $\mathrm{WOO}_{\mathrm{nf}}$ in light brown. Note that the total non-fossil concentrations (dark green markers) are on average 6 times higher compared to the fossil ones (dark grey markers).

dominating primary sources included BBOC and PBOC, whereas the most important secondary sources were SOOC $(79 \% \pm 11 \%$ non-fossil) and WOOC $(77 \% \pm 23 \%$ nonfossil).

\subsubsection{Contribution of fossil and non-fossil, primary and secondary $\mathrm{OC}$ to the total $\mathrm{OC}$}

The results point out that $81 \% \pm 11 \%$ (average and 1 standard deviation) of $\mathrm{SCOC}$ was fossil $\left(\mathrm{SCOC}_{\mathrm{f}}\right)$. Taking into account the enhanced contribution of SCOC in the coarse size fraction, its sulfur content and its fossil nature, we assume that this factor is linked to primary anthropogenic sources re- lated to traffic, such as tire wear, resuspension of road dust (Bukowiecki et al., 2010), resuspension from asphalt concrete (Gehrig et al., 2010) or asphalt mixture abrasion (in bituminous binder, Fullova et al., 2017). The contribution of $\mathrm{SCOC}_{f}$ to the $\mathrm{OC}_{f}$ was more important during autumn and winter (up to $62 \%$, Fig. 9a) in contrast to spring and summer (on average $9 \% \pm 5 \%$ ), while on average the contribution to the $\mathrm{OC}_{\mathrm{f}}$ was $20 \% \pm 19 \%$. The concentrations in winter and autumn were similar and on average for $\mathrm{PM}_{10}\left(\mathrm{PM}_{2.5}\right)$ $0.22 \pm 0.21 \mu \mathrm{g} \mathrm{m}^{-3}\left(0.03 \pm 0.03 \mu \mathrm{g} \mathrm{m}^{-3}\right)$ (Fig. 10, Table S2), which accounted for $73 \%$ of the total SCOC for this period. 

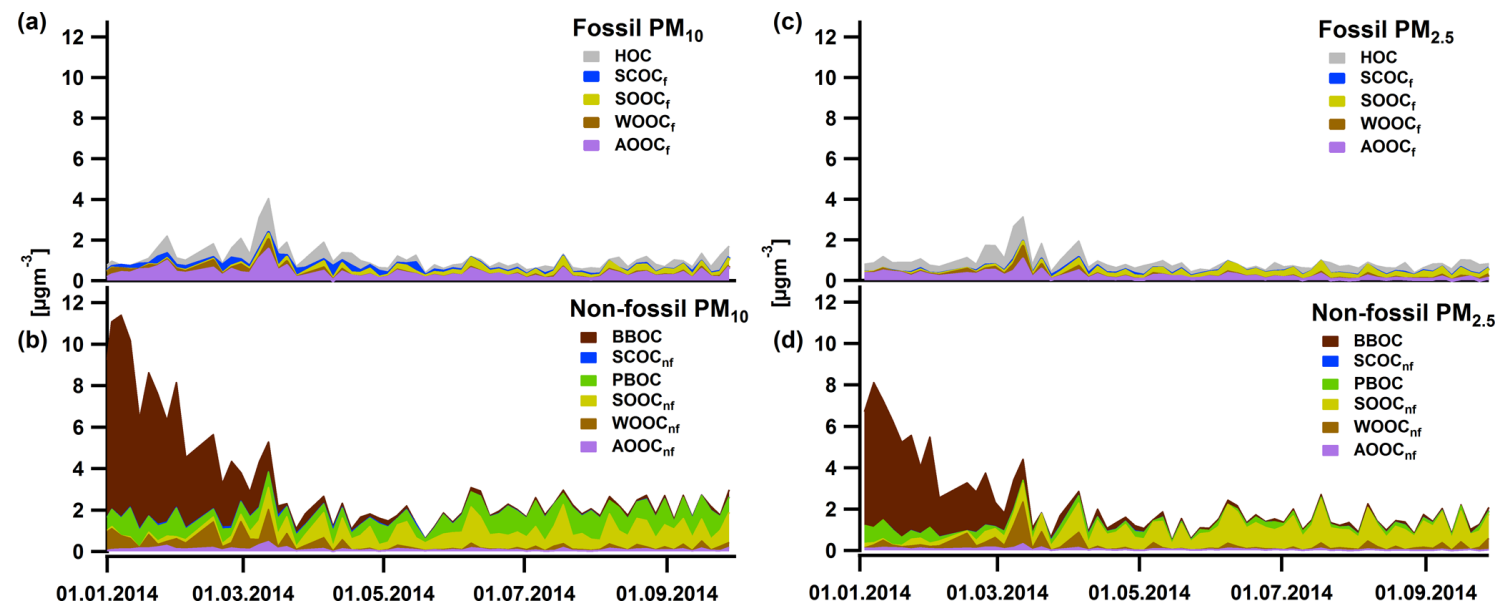

Figure 10. Yearly cycles of fossil $\mathrm{PM}_{10}$ (a), non-fossil $\mathrm{PM}_{10}$ (b), fossil $\mathrm{PM}_{2.5}$ (c), and non-fossil $\mathrm{PM}_{2.5}$ (d) $\mathrm{OC}$ factors: $\mathrm{BBOC}$ in dark brown, $\mathrm{SCOC}_{\mathrm{f}}$ and $\mathrm{SCOC}_{\mathrm{nf}}$ in blue, $\mathrm{PBOC}$ in green, $\mathrm{AOOC}_{\mathrm{f}}$ and $\mathrm{AOOC}_{\mathrm{nf}}$ in purple, $\mathrm{SOOC}_{\mathrm{f}}$ and $\mathrm{SOOC}_{\mathrm{nf}}$ in yellow, and $\mathrm{WOOC}_{\mathrm{f}}$ and $\mathrm{WOO}_{\mathrm{nf}}$ in light brown. Note that the covered time periods in (a), (b) and (c), (d) are different.

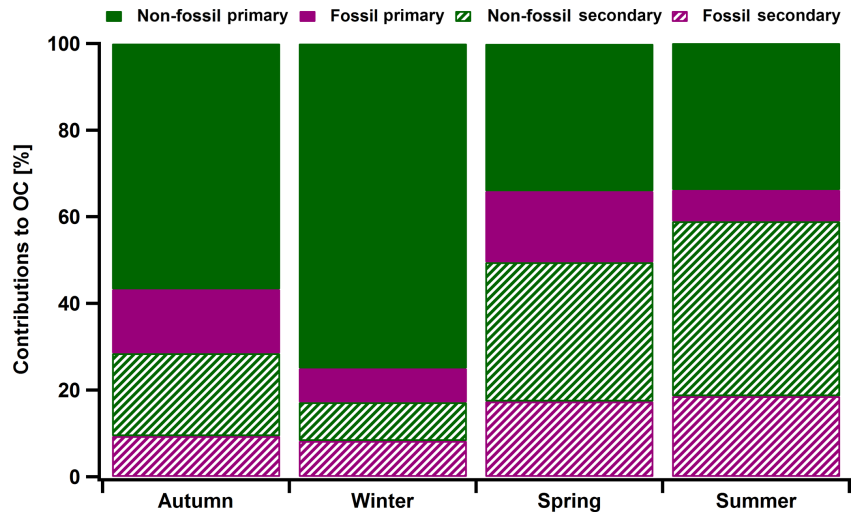

Figure 11. Averaged contributions of the fossil and non-fossil primary and secondary $\mathrm{OC}$ to the total $\mathrm{OC}$ season wise for $\mathrm{PM}_{10}$.

However, the contribution of $\mathrm{SCOC}_{\mathrm{f}}$ to the total OC for the coarse size fraction was not high ( $5 \% \pm 8 \%$ on average).

The combined ${ }^{14} \mathrm{C} / \mathrm{AMS}$ analysis supported the initial hypothesis that $\mathrm{AOOC}$ was mainly related to the oxidation of fossil fuel combustion emissions (e.g. traffic), as AOOC was $77 \% \pm 23 \%$ fossil $\left(\mathrm{AOOC}_{\mathrm{f}}\right)$ on average. The average contribution of $\mathrm{AOOC}_{\mathrm{f}}$ to the $\mathrm{OC}_{\mathrm{f}}$ was $28 \% \pm 14 \%$ (Fig. 9a), larger than $\mathrm{SCOC}_{\mathrm{f}}$, while its contribution to the total $\mathrm{OC}$ was $10 \% \pm 5 \%$ for the coarse OC and $7 \% \pm 7 \%$ of the fine OC. The yearly cycle exhibited elevated contributions in winter and spring compared to summer and autumn with average values for $\mathrm{PM}_{10}: 0.47 \pm 0.22,0.43 \pm 0.30,0.39 \pm 0.23$ and $0.29 \pm 0.23 \mu \mathrm{g} \mathrm{m}^{-3}$, respectively (Fig. 10, Table S2). In winter and spring most of the mass concentration came from the $\mathrm{PM}_{2.5}$ size range in contrast to the other two seasons.

The fossil fractions of SOOC $\left(\mathrm{SOOC}_{\mathrm{f}}\right)$ and WOOC $\left(\mathrm{WOOC}_{\mathrm{f}}\right.$ ) were low (21 and $23 \%$, respectively) and could also be attributed to traffic emissions or less likely (due to low emissions) to aged aerosols from residential fossil fuel heating. $\mathrm{SOOC}_{\mathrm{f}}$ was important during summer with contributions up to $40 \%$ to the $\mathrm{OC}_{\mathrm{f}}$ and $\mathrm{WOOC}_{\mathrm{f}}$ was more distinctively present during a few days in autumn and winter (up to $35 \%$ to the $\mathrm{OC}_{\mathrm{f}}$ ) in contrast to the rest of the year (Fig. 9a).

From the non-fossil sources, apart from non-fossil SCOC $\left(\mathrm{SCOC}_{\mathrm{nf}}\right)$ and non-fossil $\mathrm{AOOC}\left(\mathrm{AOOC}_{\mathrm{nf}}\right)$, the rest of the factors exhibited a very distinct yearly cycle with BBOC contributing up to $86 \%$ to the $\mathrm{OC}_{\mathrm{nf}}$ in late autumn and winter (Fig. 9b, yearly average $28 \% \pm 30 \%$ ) and with PBOC and $\mathrm{SOOC}_{\mathrm{nf}}$ becoming more important in late spring, summer and early autumn with contributions up to 82 and $57 \%$, respectively (Fig. 9b).

SOOC was $79 \%$ non-fossil which supported the AMS/PMF results: the significance of non-fossil SOOC $\left(\mathrm{SOOC}_{\mathrm{nf}}\right)$ during summer can be attributed to SOA formation from biogenic emissions. The average contribution of SOOC $_{\text {nf }}$ to OC $_{\text {nf }}$ was $25 \% \pm 19 \%$ (Fig. 9b). SOOC more pronounced in $\mathrm{PM}_{2.5}$ (on average $1.12 \pm 0.40 \mu \mathrm{g} \mathrm{m}^{-3}$ in summer and $0.75 \pm 0.35 \mu \mathrm{g} \mathrm{m}^{-3}$ in spring, Fig. 10 , Table S2). This factor along with PBOC was the main and almost equally important source of $\mathrm{OC}$ during spring and summer, with PBOC contributing to OC in the coarse mode (on average $35 \% \pm 16 \%$ from April to August 2014) and $\mathrm{SOOC}_{\mathrm{nf}}$ in the fine mode $(46 \% \pm 15 \%$ from April to August 2014). PBOC made up $30 \% \pm 18 \%$ of the $\mathrm{OC}_{\mathrm{nf}}$ and the average concentrations of $\mathrm{PBOC}_{\text {coarse }}$ for 2014 were $1.00 \pm 0.23 \mu \mathrm{g} \mathrm{m}^{-3}$ in summer and $0.56 \pm 0.21 \mu \mathrm{g} \mathrm{m}^{-3}$ in spring.

Non-fossil WOOC ( $\mathrm{WOOC}_{\mathrm{nf}}$ ) dominated over $\mathrm{WOOC}_{\mathrm{f}}$ (77\% over $23 \%$ ). The average yearly contribution to $\mathrm{OC}_{\mathrm{nf}}$ was low $\left(6 \% \pm 6 \%\right.$, Fig. 9b); however, WOOC $_{n f, \text { coarse }}$ was apparent during the cold period especially in 2013 with concentrations of $0.88 \pm 0.74 \mu^{-3} m^{-3}$ on average for winter $\left(0.28 \pm 0.28 \mathrm{\mu g} \mathrm{m}^{-3}\right.$ for autumn) (Fig. 10). In 
2014 the concentrations dropped for winter (autumn) with $0.53 \pm 0.43 \mu \mathrm{g} \mathrm{m}^{-3}\left(0.15 \pm 0.13 \mu \mathrm{g} \mathrm{m}^{-3}\right)$ for $\mathrm{PM}_{10}$ and $0.22 \pm 0.19 \mu \mathrm{g} \mathrm{m}^{-3}\left(0.21 \pm 0.21 \mu \mathrm{g} \mathrm{m}^{-3}\right)$ for $\mathrm{PM}_{2.5}$. Based on its yearly cycle (Fig. 10b and d) WOOC $_{\text {nf }}$ could be linked to aged $\mathrm{OA}$ influenced by wintertime and early spring biomass burning emissions. Therefore, not only $\mathrm{AOOC}_{\mathrm{f}}$ but also $\mathrm{WOOC}_{\mathrm{nf}}$ can be related to anthropogenic activities. In other studies (Daellenbach et al., 2017; Bozzetti et al., 2016) this factor was more pronounced; however, in our case in winter most of the $\mathrm{OC}_{\mathrm{nf}}$ was related to primary biomass burning.

Overall for $\mathrm{PM}_{10}$ the non-fossil primary OC contributions were more important during autumn (57\%) and winter $(75 \%)$, whereas in spring and summer the non-fossil secondary OC contributions became more pronounced (32 and $40 \%$, respectively) (Fig. 11). The dominance of the SOC during the warm period is likely related to the stronger solar radiation which favours the photo-oxidation of biogenic volatile organic compounds and to the elevated biogenic volatile organic compounds emissions.

\section{Conclusions}

The coupling of offline AMS and ${ }^{14} \mathrm{C}$ analyses allowed a detailed characterization of the carbonaceous aerosol in the Alpine valley of Magadino for the years 2013-2014. The seasonal variation along with the two size-segregated measurements $\left(\mathrm{PM}_{10}\right.$ and $\left.\mathrm{PM}_{2.5}\right)$ gave insights into the source apportionment, by for example quantifying the resuspension of road dust or asphalt concrete and estimating its contribution to the OC or by identifying SOC based on SOC precursors. More specifically, seven sources including four primary and three secondary ones were identified. The non-fossil primary sources were dominating during autumn and winter, with BBOC exhibiting by far the highest concentrations. During spring and summer again two non-fossil sources, $\mathrm{PBOC}$ in the coarse fraction and $\mathrm{SOOC}_{\mathrm{nf}}$ in the fine mode, prevailed over the fossil ones. The size-segregated measurements and ${ }^{14} \mathrm{C}$ analysis enabled a better understanding of the primary SCOC factor, which was enhanced in the coarse fraction and was mainly fossil, suggesting that it may originate from resuspension of road dust or tire - asphalt abrasion. The results also showed that SOC was formed mainly by biogenic sources during summer and anthropogenic sources during winter. However, SOC formed possibly by oxidation of traffic emissions or volatile chemical products was also apparent during summer $\left(\mathrm{AOOC}_{\mathrm{f}}\right)$. $\mathrm{AOOC}_{\mathrm{f}}$ was also important during winter along with SOC linked to transported non-fossil carbonaceous aerosols coming from anthropogenic activities such as biomass burning (WOOC ${ }_{\text {nf }}$ ).

Data availability. The data are available upon request from the corresponding author.
Supplement. The supplement related to this article is available online at: https://doi.org/10.5194/acp-18-6187-2018-supplement.

Competing interests. The authors declare that they have no conflict of interest.

Acknowledgements. This work is funded by the Swiss Federal Office for the Environment (FOEN), OSTLUFT and the cantons of Basel, Graubünden, Ticino, Thurgau and Valais. The LABEX OSUG@2020 (ANR-10-LABX-56) funded analytical instruments at IGE.

Edited by: Eleanor Browne

Reviewed by: two anonymous referees

\section{References}

Agrios, K., Salazar, G. A., Zhang, Y. L., Uglietti, C., Battaglia, M., Luginbühl, M., Ciobanu, V. G., Vonwiller, M., and Szidat, S.: Online coupling of pure $\mathrm{O}_{2}$ thermo-optical methods $-{ }^{14} \mathrm{C}$ AMS for source apportionment of carbonaceous aerosols study, Nucl. Instrum. Meth. B., 361, 288-293, https://doi.org/10.1016/j.nimb.2015.06.008, 2015.

Aiken, A. C., Decarlo, P. F., Kroll, J. H., Worsnop, D. R., Huffman, J. A., Docherty, K. S., Ulbrich, I. M., Mohr, C., Kimmel, J. R., Sueper, D., Sun, Y., Zhang, Q., Trimborn, A., Northway, M., Ziemann, P. J., Canagaratna, M. R., Onasch, Z. B., Alfarra, M. R., Prevot, A. S., Dommen, J., Duplissy, J., Metzger, A., Baltensperger, U., and Jimenez, J. L.: $\mathrm{O} / \mathrm{C}$ and $\mathrm{OM} / \mathrm{OC}$ ratios of primary, secondary, and ambient organic aerosols with high-resolution time-of-flight aerosol mass spectrometry, Environ. Sci. Technol., 42, 4478-4485, https://doi.org/10.1021/es703009q, 2008.

Alfarra, M. R., Prévôt, A. S. H., Szidat, S., Sandradewi, J.,Weimer, S., Lanz, V. A., Schreiber, D., Mohr, M., and Baltensperger, U.: Identification of the mass spectral signature of organic aerosols from wood burning emissions, Environ. Sci. Technol., 41, 57705777, https://doi.org/10.1021/es062289b, 2007.

Allan, J. D., Jimenez, J. L., Williams, P. I., Alfarra, M. R., Bower, K. N., Jayne, J. T., Coe, H., and Worsnop, D. R.: Quantitative sampling using an Aerodyne aerosol mass spectrometer - 1 . Techniques of data interpretation and error analysis, J. Geophys. Res.-Atmos., 108, 4090, https://doi.org/10.1029/2002JD002358, 2003.

Beekmann, M., Prévôt, A. S. H., Drewnick, F., Sciare, J., Pandis, S. N., Denier van der Gon, H. A. C., Crippa, M., Freutel, F., Poulain, L., Ghersi, V., Rodriguez, E., Beirle, S., Zotter, P., von der Weiden-Reinmüller, S. L., Bressi, M., Fountoukis, C., Petetin, H., Szidat, S., Schneider, J., Rosso, A., El Haddad, I., Megaritis, A., Zhang, Q. J., Michoud, V., Slowik, J. G., Moukhtar, S., Kolmonen, P., Stohl, A., Eckhardt, S., Borbon, A., Gros, V., Marchand, N., Jaffrezo, J. L., Schwarzenboeck, A., Colomb, A., Wiedensohler, A., Borrmann, S., Lawrence, M., Baklanov, A., and Baltensperger, U.: In situ, satellite measurement and model evidence on the dominant regional contribution to fine particu- 
late matter levels in the Paris megacity, Atmos. Chem. Phys., 15, 9577-9591, https://doi.org/10.5194/acp-15-9577-2015, 2015.

Bonvalot, L., Tuna, T., Fagault, Y., Jaffrezo, J. L., Jacob, V., Chevrier, F., and Bard, E.: Estimating contributions from biomass burning and fossil fuel combustion by means of radiocarbon analysis of carbonaceous aerosols: application to the Valley of Chamonix, Atmos. Chem. Phys., 16, 13753-13772, https://doi.org/10.5194/acp-16-13753-2016, 2016.

Bozzetti, C., Daellenbach, K., R., Hueglin, C., Fermo, P., Sciare, J., Kasper-Giebl, A., Mazar, Y., Abbaszade, G., El Kazzi, M., Gonzalez, R., Shuster Meiseles, T., Flasch, M., Wolf, R., Křepelová, A., Canonaco, F., Schnelle-Kreis, J., Slowik, J. G., Zimmermann, R., Rudich, Y., Baltensperger, U., El Haddad, I., and Prévôt, A. S. H.: Size-resolved identification, characterization, and quantification of primary biological organic aerosol at a European rural site, Environ. Sci. Technol., 50, 3425-3434, https://doi.org/10.1021/acs.est.5b05960, 2016.

Bozzetti, C., Sosedova, Y., Xiao, M., Daellenbach, K. R., Ulevicius, V., Dudoitis, V., Mordas, G., Byčenkienè, S., Plauškaite, K., Vlachou, A., Golly, B., Chazeau, B., Besombes, J.-L., Baltensperger, U., Jaffrezo, J.-L., Slowik, J. G., El Haddad, I., and Prévôt, A. S. H.: Argon offline-AMS source apportionment of organic aerosol over yearly cycles for an urban, rural, and marine site in northern Europe, Atmos. Chem. Phys., 17, 117-141, https://doi.org/10.5194/acp-17-117-2017, 2017a.

Bozzetti, C., El Haddad, I., Salameh, D., Daellenbach, K. R., Fermo, P., Gonzalez, R., Minguillón, M. C., Iinuma, Y., Poulain, L., Elser, M., Müller, E., Slowik, J. G., Jaffrezo, J.-L., Baltensperger, U., Marchand, N., and Prévôt, A. S. H.: Organic aerosol source apportionment by offline-AMS over a full year in Marseille, Atmos. Chem. Phys., 17, 8247-8268, https://doi.org/10.5194/acp-17-8247-2017, 2017b.

Bruns E., Krapf, M., Orasche, J., Huang, Y., Zimmermann, R., Drinovec, L., Močnik, G., El-Haddad, I., Slowik, J. G., Dommen, J., Baltensperger, U., and Prévôt, A. S. H.: Characterization of primary and secondary wood combustion products generated under different burner loads, Atmos., Chem., Phys., 15, 2825-2841, https://doi.org/10.5194/acp-15-2825-2015, 2015.

Bukowiecki, N., Lienemann, P., Hill, M., Furger, M., Richard, A., Amato, F., Prevot, A. S. H., Baltensperger, U., Buchmann, B., and Gehrig, R.: $\mathrm{PM}_{10}$ emission factors for non-exhaust particles generated by road traffic in an urban street canyon and along a freeway in Switzerland, Atmos. Environ., 44, 23302340, https://doi.org/10.1016/j.atmosenv.2010.03.039, 2010.

Canagaratna, M. R., Jayne, J. T., Jimenez, J. L., Allan, J. D., Alfarra, M. R., Zhang, Q., Onasch, T. B., Drewnick, F., Coe, H., Middlebrook, A., Delia, A., Williams, L. R., Trimborn, A. M., Northway, M. J., DeCarlo, P. F., Kolb, C. E., Davidovits, P., and Worsnop, D. R.: Chemical and microphysical characterization of ambient aerosols with the Aerodyne aerosol mass spectrometer, Mass Spectrom. Rev., 26, 185-222, https://doi.org/10.1002/mas.20115, 2007.

Canonaco, F., Crippa, M., Slowik, J. G., Baltensperger, U., and Prévôt, A. S. H.: SoFi, an IGOR-based interface for the efficient use of the generalized multilinear engine (ME2) for the source apportionment: ME-2 application to aerosol mass spectrometer data, Atmos. Meas. Tech., 6, 3649-3661, https://doi.org/10.5194/amt-6-3649-2013, 2013.
Canonaco, F., Slowik, J. G., Baltensperger, U., and Prévôt, A. S. H.: Seasonal differences in oxygenated organic aerosol composition: implications for emissions sources and factor analysis. Atmos. Chem. Phys. 15, 6993-7002, https://doi.org/10.5194/acp15-6993-2015, 2015.

Cavalli, F., Viana, M., Yttri, K. E., Genberg, J., and Putaud, J.-P.: Toward a standardised thermal-optical protocol for measuring atmospheric organic and elemental carbon: the EUSAAR protocol, Atmos. Meas. Tech., 3, 79-89, https://doi.org/10.5194/amt-3-792010, 2010.

Chirico, R., Prevot A. S. H., DeCarlo P. F., Heringa M. F., Richter R., Weingartner E., and Baltensperger U.: Aerosol and trace gas vehicle emission factors measured in a tunnel using an aerosol mass spectrometer and other online instrumentation, Atmos. Environ., 45, 2182-2192, https://doi.org/10.1016/j.atmosenv.2011.01.069, 2011.

Crippa, M., El Haddad, I., Slowik, J. G., DeCarlo, P.F., Mohr, C., Heringa, M. F., Chirico, R., Marchand, N., L., Sciare, J., Baltensperger, U., and Prévôt, A. S. H.: Identification of marine and continental aerosol sources in Paris using high resolution aerosol mass spectrometry, J. Geophys. Res., 118, 1950-1963, https://doi.org/10.1002/jgrd.50151, 2013.

Daellenbach, K. R., Bozzetti, C., Krepelova, A., Canonaco, F., Huang, R.-J., Wolf, R., Zotter, P., Crippa, M., Slowik, J., Zhang, Y., Szidat, S., Baltensperger, U., Prévôt, A. S. H., and El Haddad, I.: Characterization and source apportionment of organic aerosol using offline aerosol mass spectrometry, Atmos. Meas. Tech., 9, 23-39, https://doi.org/10.5194/amt-9-23-2016, 2016.

Daellenbach K. R., Stefenelli G., Bozzetti C., Vlachou A., Fermo P., Gonzalez R., Piazzalunga A., Colombi C., Canonaco F., Kasper-Giebl A., Jaffrezo J.-L., Bianchi F., Slowik J. G., Baltensperger U., El-Haddad I., and Prévôt A. S. H.: Long-term chemical analysis and organic aerosol source apportionment at 9 sites in Central Europe: Source identification and uncertainty assessment, Atmos. Chem. Phys., 17, 13265-13282, https://doi.org/10.5194/acp-2017-124, 2017.

Davison, A. C. and Hinkley, D. V.: Bootstrap Methods and Their Application, Cambridge University Press, Cambridge, UK, 582 pp., 1997.

Dusek, U., Hitzenberger, R., Kasper-Giebl, A., Kistler, M., Meijer, H. A. J., Szidat, S., Wacker, L., Holzinger, R., and Röckmann, T.: Sources and formation mechanisms of carbonaceous aerosol at a regional background site in the Netherlands: insights from a year-long radiocarbon study, Atmos. Chem. Phys., 17, 32333251, https://doi.org/10.5194/acp-17-3233-2017, 2017.

El Haddad, I., Marchand, N., Dron, J., Temime-Roussel, B., Quivet, E., Wortham, H., Jaffrezo, J-L., Baduel, C., Voisin, D., Besombes, J. L., and Gille, G.: Comprehensive primary particulate organic characterization of vehicular exhaust emissions in France, Atmos. Environ., 43, 6190-6198, https://doi.org/10.1016/j.atmosenv.2009.09.001, 2009.

El Haddad, I., D’Anna, B., Temime-Roussel, B., Nicolas, M., Boreave, A., Favez, O., Voisin, D., Sciare, J., George, C., Jaffrezo, J. L., Wortham, H., and Marchand, N.: Towards a better understanding of the origins, chemical composition and aging of oxygenated organic aerosols: case study of a Mediterranean industrialized environment, Marseille, Atmos. Chem. Phys., 13, 78757894, https://doi.org/10.5194/acp-13-7875-2013, 2013. 
Elser, M., Huang, R.-J., Wolf, R., Slowik, J. G., Wang, Q., Canonaco, F., Li, G., Bozzetti, C., Daellenbach, K. R., Huang, Y., Zhang, R., Li, Z., Cao, J., Baltensperger, U., El-Haddad, I., Prévôt, A. S. H., and André, S. H.: New insights into $\mathrm{PM}_{2.5}$ chemical composition and sources in two major cities in China during extreme haze events using aerosol mass spectrometry, Atmos. Chem. Phys., 16, 3207-3225, https://doi.org/10.5194/acp16-3207-2016, 2016.

Favez, O., El Haddad, I., Piot, C., Boréave, A., Abidi, E., Marchand, N., Jaffrezo, J.-L., Besombes, J.-L., Personnaz, M.-B., Sciare, J., Wortham, H., George, C., and D'Anna, B.: Intercomparison of source apportionment models for the estimation of wood burning aerosols during wintertime in an Alpine city (Grenoble, France), Atmos. Chem. Phys., 10, 5295-5314, https://doi.org/10.5194/acp-10-5295-2010, 2010.

Fröhlich, R., Cubison, M. J., Slowik, J. G., Bukowiecki, N., Prevot, A. S. H., Baltensperger, U., Schneider, J., Kimmel, J. R., Gonin, M., Rohner, U., Worsnop, D. R., and Jayne J. T.: The ToF-ACSM: a portable aerosol chemical speciation monitor with TOFMS detection, Atmos. Meas. Tech., 6, 3225-3241, https://doi.org/10.5194/amt-6-3225-2013, 2013.

Fullova, D., Durcanska D., and Hegrova, J.: Particulate matter mass concentrations produced from pavement surface abrasion, MATEC Web of Conferences, 117, 00048, https://doi.org/10.1051/matecconf/201711700048, 2017.

Gehrig, R., Zeyer, K., Bukowiecki, N., Lienemann, P., Poulikakos, L. D., Furger, M., and Buchmann, B.: Mobile load simulators - A tool to distinguish between the emissions due to abrasion and resuspension of $\mathrm{PM}_{10}$ from road surfaces, Atmos. Environ., 44, 4937-4943, https://doi.org/10.1016/j.atmosenv.2010.08.020, 2010.

Gelencsér, A., May, B., Simpson, D., Sánchez-Ochoa, A., KasperGiebl, A., Puxbaum, H., Caseiro, A., Pio, C., and Legrand, M.: Source apportionment of $\mathrm{PM}_{2.5}$ organic aerosol over Europe: Primary/secondary, natural/anthropogenic, and fossil/biogenic origin, J. Geophys. Res.-Atmos., 112, D23S04, https://doi.org/10.1029/2006JD008094, 2007.

Genberg, J., Hyder, M., Stenström, K., Bergström, R., Simpson, D., Fors, E. O., Jönsson, J. Å., and Swietlicki, E.: Source apportionment of carbonaceous aerosol in southern Sweden, Atmos. Chem. Phys., 11, 11387-11400, https://doi.org/10.5194/acp-1111387-2011, 2011.

Gianini, M. F. D., Gehrig, R., Fischer, A., Ulrich, A., Wichser, A., and Hueglin, C.: Chemical composition of $\mathrm{PM}_{10}$ in Switzerland: An analysis for 2008/2009 and changes since 1998/1999, Atmos. Environ., 54, 97-106, https://doi.org/10.1016/j.atmosenv.2012.02.037, 2012.

Gilardoni, S., Vignati, E., Cavalli, F., Putaud, J. P., Larsen, B. R., Karl, M., Stenström, K., Genberg, J., Henne, S., and Dentener, F.: Better constraints on sources of carbonaceous aerosols using a combined ${ }^{14} \mathrm{C}$ - macro tracer analysis in a European rural background site, Atmos. Chem. Phys., 11, 5685-5700, https://doi.org/10.5194/acp-11-5685-2011, 2011.

Glasius, M., la Cour, A., and Lohse, C.: Fossil and nonfossil carbon in fine particulate matter: A study of five European cities, J. Geophys. Res., 116, D11302, https://doi.org/10.1029/2011JD015646, 2011.

Heaton, K. J., Dreyfus, M. A., Wang, S., and Johnston, M. V.: Oligomers in the early stage of biogenic secondary organic aerosol formation and growth, Environ. Sci. Technol., 41, 61296136, https://doi.org/10.1021/es070314n, 2007.

Herich, H., Gianini, M. F. D., Piot, C., Močnik, G., Jaffrezo, J. L., Besombes, J. L., Prévôt, A. S. H., and Hueglin, C.: Overview of the impact of wood burning emissions on carbonaceous aerosols and PM in large parts of the Alpine region, Atmos. Environ., 89, 64-75, https://doi.org/10.1016/j.atmosenv.2014.02.008, 2014.

Huang, R.-J., Zhang, Y., Bozzetti, C., Ho, K.-F., Cao, J., Han, Y., Dällenbach, K. R., Slowik, J. G., Platt, S. M., Canonaco, F., Zotter, P., Wolf, R., Pieber, S. M., Bruns, E. A., Crippa, M., Ciarelli, G., Piazzalunga, A., Schwikowski, M., Abbaszade, G., SchnelleKreis, J., Zimmermann, R., An, Z., Szidat, S., Baltensperger, U., Haddad, I. E., and Prévôt, A. S. H.: High secondary aerosol contribution to particulate pollution during haze events in China, Nature, 514, 218-222, https://doi.org/10.1038/nature13774, 2014.

Jaffrezo, J.-L., Calas, T., and Bouchet, M.: Carboxylic acids measurements with ionic chromatography, Atmos. Environ., 32, 2705-2708, https://doi.org/10.1016/S1352-2310(98)000260,1998 .

Jaffrezo, J.-L., Aymoz, G., Delaval, C., and Cozic, J.: Seasonal variations of the water soluble organic carbon mass fraction of aerosol in two valleys of the French Alps, Atmos. Chem. Phys., 5, 2809-2821, https://doi.org/10.5194/acp-5-2809-2005, 2005.

Jimenez, J. L., Canagaratna, M. R., Donahue, N. M., Prévôt, A. S. H., Zhang, Q., Kroll, J. H., DeCarlo, P. F., Allan, J. D., Coe, H., Ng, N. L., Aiken, A. C., Docherty, K. S., Ulbrich, I. M., Grieshop, A. P., Robinson, A. L., Duplissy, J., Smith, J. D., Wilson, K. R., Lanz, V. A., Hueglin, C., Sun, Y. L., Tian, J., Laaksonen, A., Raatikainen, T., Rautiainen, J., Vaattovaara, P., Ehn, M., Kulmala, M., Tomlinson, J. M., Collins, D. R., Cubison, M. J., Dunlea, E. J., Huffman, J. A., Onasch, T. B., Alfarra, M. R., Williams, P. I., Bower, K., Kondo, Y., Schneider, J., Drewnick, F., Borrmann, S., Weimer, S., Demerjian, K., Salcedo, D., Cottrell, L., Griffin, R., Takami, A., Miyoshi, T., Hatakeyama, S., Shimono, A., Sun, J. Y., Zhang, Y. M., Dzepina, K., Kimmel, J. R., Sueper, D., Jayne, J. T., Herndon, S. C., Trimborn, A. M., Williams, L. R., Wood, E. C., Middlebrook, A. M., Kolb, C. E., Baltensperger, U., and Worsnop, D. R.: Evolution of organic aerosols in the atmosphere, Science, 326, 1525-1529, https://doi.org/10.1126/science.1180353, 2009.

Kunit, M. and Puxbaum, H.: Enzymatic determination of the cellulose content of atmospheric aerosols, Atmos. Environ., 30, 1233 1236, https://doi.org/10.1016/1352-2310(95)00429-7, 1996.

Lanz, V. A., Alfarra, M. R., Baltensperger, U., Buchmann, B., Hueglin, C., and Prévôt, A. S. H.: Source apportionment of submicron organic aerosols at an urban site by factor analytical modelling of aerosol mass spectra, Atmos. Chem. Phys., 7, 15031522, https://doi.org/10.5194/acp-7-1503-2007, 2007.

Lanz, V. A., Prévôt, A. S. H., Alfarra, M. R., Weimer, S., Mohr, C., DeCarlo, P. F., Gianini, M. F. D., Hueglin, C., Schneider, J., Favez, O., D’Anna, B., George, C., and Baltensperger, U.: Characterization of aerosol chemical composition with aerosol mass spectrometry in Central Europe: an overview, Atmos. Chem. Phys., 10, 10453-10471, https://doi.org/10.5194/acp-10-104532010, 2010.

Leaitch, W. R. Macdonald, A. M., Brickell, P. C., Liggio, J., Sjostedt, S. J., Vlasenko, A., Bottenheim, J. W., Huang, L., Li, S.-M., Liu, P. S. K., Toom-Sauntry, D., Hayden, K. A., Sharma, S., Shantz, N. C., Wiebe H. A., Zhang, W., Ab- 
batt, J. P. D., Slowik, J. G., Chang, Rachel, Y.-W., Russell, L. M., Schwartz, R. E., Takahama, S., Jayne, J. T., and $\mathrm{Ng}$, N. L.: Temperature response of the submicron organic aerosol from temperate forests, Atmos. Environ., 45, 6696-6704, https://doi.org/10.1016/j.atmosenv.2011.08.047, 2011.

Lemire, R. K., Allen, T. D., Klouda A. G., and Lewis W. C.: Fine particulate matter source attribution for Southeast Texas using ${ }^{14} \mathrm{C} /{ }^{13} \mathrm{C}$ ratios, J. Geophys. Res., 107, 4631, https://doi.org/10.1029/2002JD002339, 2002.

Levin, I., Naegler, T., Kromer, B., Diehl, M., Francey, R. J., GomezPelaez, A. J., Steele, L. P., Wagenbach, D., Weller, R., and Worthy, D. E.: Observations and modelling of the global distribution and long-term trend of atmospheric ${ }^{14} \mathrm{CO}_{2}$, Tellus B, 62, 26-46, https://doi.org/10.1111/j.1600-0889.2009.00446.x, 2010a.

Levin, E. J. T., McMeeking, G. R., Carrico, C. M., Mack, L. E., Kreidenweis, S. M., Wold, C. E., Moosmüller, H., Arnott, W. P., Hao, W. M., Collett, J. L., and Malm, W. C.: Biomass burning smoke aerosol properties measured during Fire Laboratory at Missoula Experiments (FLAME), J. Geophys. Res.-Atmos., 115, D18210, https://doi.org/10.1029/2009jd013601, 2010 b.

Li, X. Dallmann, T. R., May, A. A., Tkacik, D. S., Lambe, A. T., Jayne, J. T., Croteau, P. L., and Presto, A. A.: Gas-particle partitioning of vehicle emitted primary organic aerosol measured in a traffic tunnel, Environ. Sci. Technol., 50, 12146-12155, https://doi.org/10.1021/acs.est.6b01666, 2016.

McDonald, B. C., de Gouw, J. A., Gilman, J. B., Jathar, S. H., Akherati, A., Cappa, C. D., Jimenez, J. L.,Lee-Taylor, J.,Hayes, P. L.,McKeen, S. A., Cui, Y. Y., Kim, S.-W.,Gentner, Drew R., Isaacman-VanWertz, G., Goldstein, A. H.,Harley, R. A., Frost, G. J., Roberts, J. M., Ryerson, T. B., and Trainer, M.: Volatile chemical products emerging as largest petrochemical source of urban organic emissions, Science, 359, 760-764, https://doi.org/10.1126/science.aaq0524, 2018.

Minguillón, M. C., Perron, N., Querol, X., Szidat, S., Fahrni, S. M., Alastuey, A., Jimenez, J. L., Mohr, C., Ortega, A. M., Day, D. A., Lanz, V. A., Wacker, L., Reche, C., Cusack, M., Amato, F., Kiss, G., Hoffer, A., Decesari, S., Moretti, F., Hillamo, R., Teinilä, K., Seco, R., Peñuelas, J., Metzger, A., Schallhart, S., Müller, M., Hansel, A., Burkhart, J. F., Baltensperger, U., and Prévôt, A. S. H.: Fossil versus contemporary sources of fine elemental and organic carbonaceous particulate matter during the DAURE campaign in Northeast Spain, Atmos. Chem. Phys., 11, 1206712084, https://doi.org/10.5194/acp-11-12067-2011, 2011.

Mohn, J., Szidat, S., Fellner, J., Rechberger, H., Quartier, R., Buchmann, B., and Emmenegger, L.: Determination of biogenic and fossil $\mathrm{CO}_{2}$ emitted by waste incineration based on ${ }^{14} \mathrm{CO}_{2}$ and mass balances, Bioresource Technol., 99, 64716479, https://doi.org/10.1016/j.biortech.2007.11.042, 2008.

Ng, N. L., Herndon, S. C., Trimborn, A., Canagaratna, M. R. Croteau, P. L., Onasch, T. B. Sueper, D., Worsnop, D. R., Zhang, Q., Sun, Y. L., and Jayne, J. T.: An Aerosol Chemical Speciation Monitor (ACSM) for routine monitoring of the composition and mass concentrations of ambient aerosol, Aerosol Sci. Tech., 45, 770-784, https://doi.org/10.1080/02786826.2011.560211, 2011.

Paatero, P.: Least squares formulation of robust non-negative factor analysis, Chemom. Intell. Lab. Syst., 37, 23-35, https://doi.org/10.1016/S0169-7439(96)00044-5, 1997.

Paatero, P.: The multilinear engine - A table-driven, least squares program for solving multilinear problems, including the n-way parallel factor analysis model, J. Comput. Graph. Stat., 8, 854888, 1999.

Paatero, P. and Hopke, P. K.: Discarding or downweighting highnoise variables in factor analytic models, Anal. Chim. Acta, 490, 277-289, https://doi.org/10.1016/s0003-2670(02)01643-4, 2003.

Paatero, P. and Tapper U.: Positive matrix factorization: A non-negative factor model with optimal utilization of error estimates of data values, Environmetrics, 5, 111-126, https://doi.org/10.1002/env.3170050203,1994.

Piazzalunga, A., Bernardoni, V., Fermo, P., Valli, G., and Vecchi, R.: Technical Note: On the effect of water-soluble compounds removal on EC quantification by TOT analysis in urban aerosol samples, Atmos. Chem. Phys., 11, 10193-10203, https://doi.org/10.5194/acp-11-10193-2011, 2011.

Pieber, S. M., El Haddad, I., Slowik, J. G., Canagaratna, M. R., Jayne, J. T., Platt, S. M., Bozzetti, C., Daellenbach, K. R., Fröhlich, R., Vlachou, A., Klein, F., Dommen, J., Miljevic, B., Jimenez, J. L., Worsnop, D. R., Baltensperger, U., and Prévôt, A. S. H.: Inorganic salt interference on $\mathrm{CO}_{2}^{+}$in aerodyne AMS and ACSM organic aerosol composition studies, Environ. Sci. Technol., 50, 10494-10503, https://doi.org/10.1021/acs.est.6b01035, 2016.

Puxbaum, H., Caseiro, A., Sànchez-Ochoa, A., Kasper-Giebl, A., Claeys, M., Gelencser, A, Legrand, M., Preunkert S., and Pio, C.: Levoglucosan levels at background sites in Europe for assessing the impact of biomass combustion on the European aerosol background, J. Geophys. Res., 112, D23S05, https://doi.org/10.1029/2006JD008114, 2007.

Sandradewi, J., Prévôt, A. S. H., Alfarra, M. R., Szidat, S.,Wehrli, M. N., Ruff, M., Weimer, S., Lanz, V. A., Weingartner, E., Perron, N., Caseiro, A., Kasper-Giebl, A., Puxbaum, H., Wacker, L., and Baltensperger, U.: Comparison of several wood smoke markers and source apportionment methods for wood burning particulate mass, Atmos. Chem. Phys. Discuss., 8, 8091-8118, https://doi.org/10.5194/acpd-8-8091-2008, 2008.

Schichtel, B. A., Malm, W. C., Bench, G., Fallon, S., McDade, C. E., Chow, J. C., and Watson, J. G.: Fossil and contemporary fine particulate carbon fractions at 12 rural and urban sites in the United States, J. Geophys. Res., 113, D02311, https://doi.org/10.1029/2007JD008605, 2008.

Stuiver, M. and Polach, H. A.: Reporting of ${ }^{14} \mathrm{C}$ data, Radiocarbon, 19, 355-363, https://doi.org/10.1017/S0033822200003672, 1977.

Szidat, S., Jenk, T. M., Gäggeler, H. W., Synal, H. A., Fisseha, R., Baltensperger, U., Kalberer, M., Samburova, V., Reimann, S., Kasper-Giebl, A., and Hajdas, I.: Radiocarbon $\left({ }^{14} \mathrm{C}\right)$-deduced biogenic and anthropogenic contributions to organic carbon (OC) of urban aerosols from Zürich, Switzerland, Atmos. Environ. 38, 4035-4044, https://doi.org/10.1016/j.atmosenv.2004.03.066, 2004.

Szidat, S., Prévôt, A. S. H., Sandradewi, J., Alfarra, M. R., Synal, H.-A., Wacker, L., and Baltensperger, U.: Dominant impact of residential wood burning on particulate matter in Alpine valleys during winter, Geophys. Res. Lett., 34, L5820, https://doi.org/10.1029/2006gl028325, 2007.

Szidat, S., Ruff, M., Perron, N., Wacker, L. Synal, H. A., Hallquist, M., Shannigrahi, A. S., Yttri, K. E., Dye, C., and Simpson, D. Fossil and non-fossil sources of organic carbon (OC) and ele- 
mental carbon (EC) in Göteborg, Sweden, Atmos. Chem. Phys, 9, 1521-1535, https://doi.org/10.5194/acp-9-1521-2009, 2009.

Szidat, S., Salazar, G. A., Vogel, E., Battaglia, M., Wacker, L., Synal, H.-A., and Türler, A.: ${ }^{14} \mathrm{C}$ analysis and sample preparation at the new Bern Laboratory for the Analysis of Radiocarbon with AMS (LARA), Radiocarbon, 56, 561-566, https://doi.org/10.2458/56.17457, 2014.

Turpin, B. J. and Lim, H-J.: Species contributions to PM2.5 mass concentrations: revisiting common assumptions for estimating organic mass, Aerosol Sci. Technol., 35, 602-610, https://doi.org/10.1080/02786820119445, 2001.

Ulbrich, I. M., Canagaratna, M. R., Zhang, Q., Worsnop, D. R., and Jimenez, J. L.: Interpretation of organic components from Positive Matrix Factorization of aerosol mass spectrometric data, Atmos. Chem. Phys., 9, 2891-2918, https://doi.org/10.5194/acp-92891-2009, 2009.

Ulevicius, V., Byčenkienè, S., Bozzetti, C., Vlachou, A., Plauškaitė, K., Mordas, G., Dudoitis, V., Abbaszade, G.,Remeikis, V., Garbaras, A., Masalaite, A., Blees, J., Fröhlich, R., Dällenbach, K. R., Canonaco, F., Slowik, J. G., Dommen, J., Zimmermann, R., Schnelle-Kreis, J., Salazar, G. A., Agrios, K., Szidat, S., El Haddad, I., and Prévôt, A. S. H.: Fossil and non-fossil source contributions to atmospheric carbonaceous aerosols during extreme spring grassland fires in Eastern Europe, Atmos. Chem. Phys, 16, 5513-5529, https://doi.org/10.5194/acp-16-5513-2016, 2016.

Williams, L. R., Gonzalez, L. A., Peck, J., Trimborn, D., McInnis, J., Farrar, M. R., Moore, K. D., Jayne, J. T., Robinson, W. A., Lewis, D. K., Onasch, T. B., Canagaratna, M. R., Trimborn, A., Timko, M. T., Magoon, G., Deng, R., Tang, D., de la Rosa Blanco, E., Prévôt, A. S. H., Smith, K. A., and Worsnop, D. R.: Characterization of an aerodynamic lens for transmitting particles greater than 1 micrometer in diameter into the Aerodyne aerosol mass spectrometer, Atmos. Meas. Tech., 6, 3271-3280, https://doi.org/10.5194/amt-6-3271-2013, 2013.

$\mathrm{Xu}$, L., Guo, H., Weber, R. J., and Ng, N. L.: Chemical characterization of water-soluble organic aerosol in contrasting rural and urban environments in the Southeastern United States, Environ. Sci. Technol., 51, 78-88, https://doi.org/10.1021/acs.est.6b05002, 2017.
Zhang, Y. L., Perron, N., Ciobanu, V. G., Zotter, P., Minguillón, M. C., Wacker, L., Prévôt, A. S. H., Baltensperger, U., and Szidat, S.: On the isolation of OC and EC and the optimal strategy of radiocarbon-based source apportionment of carbonaceous aerosols, Atmos. Chem. Phys., 12, 10841-10856, https://doi.org/10.5194/acp-12-10841-2012, 2012.

Zhang, Y. L., Zotter P., Perron N., Prévôt, A. S. H, Wacker L., and Szidat, S.: Fossil and non-fossil sources of different carbonaceous fractions in fine and coarse particles by radiocarbon measurement, Radiocarbon, 55, 1510-1520, https://doi.org/10.2458/azu_js_rc.55.16278, 2013.

Zhang, Y. L., Kawamura, K., Agrios, K., Lee, M., Salazar G., and Szidat, S.: Fossil and nonfossil sources of organic and elemental carbon aerosols in the outflow from Northeast China, Environ. Sci. Technol. 50, 6284-6292, https://doi.org/10.1021/acs.est.6b00351, 2016.

Zhang, Y. L., Ren, H., Sun, Y., Cao, F., Chang, Y., Liu, S., Lee, X., Agrios, K., Kawamura, K., Liu, D., Ren, L., Du, W., Wang, Z., Prevot, A. S. H., Szidat, S., and Fu, P. Q.: High contribution of non-fossil sources to submicrometer organic aerosols in Beijing, China, Environ. Sci. Technol. 51, 78427852, https://doi.org/10.1021/acs.est.7b01517, 2017.

Zotter, P., El-Haddad, I., Zhang, Y. L., Hayes, P. L., Zhang, X., Lin, Y.-H., Wacker, L., Schnelle-Kreis, J., Abbaszade, G., Zimmermann, R., Surratt, J. D., Weber, R., Jimenez, J. L., Szidat, S., Baltensperger, U., and Prévôt, A. S. H.: Diurnal cycle of fossil and nonfossil carbon using radiocarbon analyses during CalNex, J. Geophys. Res.-Atmos., 119, 6818-6835, https://doi.org/10.1002/2013jd021114, 2014a.

Zotter, P., Ciobanu, V. G., Zhang, Y. L., El-Haddad, I., Macchia, M., Daellenbach, K. R., Salazar, G. A., Huang, R.-J., Wacker, L., Hueglin, C., Piazzalunga, A., Fermo, P., Schwikowski, M., Baltensperger, U., Szidat, S., and Prévôt, A. S. H.: Radiocarbon analysis of elemental and organic carbon in Switzerland during winter-smog episodes from 2008 to 2012 - Part 1: Source apportionment and spatial variability, Atmos. Chem. Phys., 14, 1355113570, https://doi.org/10.5194/acp-14-13551-2014, 2014b. 